Original Research Paper

\title{
Evaluating Plant Species Suitability for a Substrate-Free Tropical Green Roof
}

\author{
${ }^{1}$ Bruno R. Silva, ${ }^{2}$ André Mantovani, ${ }^{3}$ Dulce G. Mantuano, ${ }^{4}$ Sylvia Meimaridou Rola and ${ }^{5}$ Maria C. Barbosa \\ ${ }^{1}$ Curatorship of Living Collections, Research Institute of Rio de Janeiro Botanical Garden, \\ Rua Pacheco Leão, 915, Bromeliário, Horto, Rio de Janeiro, RJ, Brasil, CEP 22460-030 \\ ${ }^{2}$ Structural Botany Laboratory, Research Institute of Rio de Janeiro Botanical Garden, Brazil \\ ${ }^{3}$ Plant Ecophysiology Laboratory, Biology Institute, Botany Department, \\ Federal University of Rio de Janeiro, Cidade Universitária, Rio de Janeiro, RJ, Brasil, CEP 21941-901 \\ ${ }^{4}$ Postgraduation Program of Architecture (PROARQ) - Department of Construction Technology, \\ Faculty of Architecture, Federal University of Rio de Janeiro, \\ Cidade Universitária, Rio de Janeiro, RJ, Brazil, CEP 21941-901 \\ ${ }^{5}$ Geotechnical Laboratory Prof. Jacques Medina - LABGEO, Coppe, \\ Federal University of Rio de Janeiro, Cidade Universitária, Rio de Janeiro, RJ, Brazil, CEP 21941-901
}

Article history

Received: 09-03-2018

Revised: $18-07-2018$

Accepted: 08-10-2018

Corresponding Author:

Andre Mantovani

Structural Botany Laboratory,

Research Institute of Rio de

Janeiro Botanical Garden,

Brazil

Email: andre@jbrj.gov.br

\begin{abstract}
Greenroofs reduce building exterior-interior thermal flux and mitigate high internal air temperatures, especially in tropical climates. Tropical greenroofs are given little attention and their use remains restricted to a very low percentage of roofs due to high costs compared to traditional roofs, weight overload (mainly due to the chosen substrate) and potential waterproofing problems. We here present an alternative greenroof technique based on a reduction of the current Modern Extensive Greenroof (MEG) technique to half of its original layers. The feasibility of superficially rooting plant species from extreme habitats was tested in full scale on a single family house over three consecutive years. The innovative horticultural system is based on a substrate-free method, which has several advantages over traditional systems, including easier maintenance and minimal total weight. The reduced layout also lowers material and labor costs, facilitating widespread retrofitting of installations, mainly on low income houses in urban areas of developing countries. From a sparse initial planting, total coverage was attained in two years and 218 taxa, belonging to 20 families and various growth types, were successfully grown on the new greenroof system. Species were able to survive and grow even though signs of dynamic photoinhibition were detected. The viability of the plant assemblage together with the ability to store water due to a high degree of succulence among species indicates a broad potential for research into the use of cultivated epiphytic, lithophytic and psammophilous flora for the installation of tropical greenroofs.
\end{abstract}

Keywords: Greenroof, Substrate-Free, Tropical, Epithyte, Lithophyte

\section{Introduction}

Urban green areas and local temperature reductions are intimately related (Susca et al., 2011). Poor vegetation coverage is common in densely urbanized areas, which have very few residual spaces on the ground level that can be greened (Madre et al., 2014). Thus, attention was increasingly turned towards the greening of roofs, which constitutes from 20-25\% (Akbari et al., 2003) to over 30\% (Frazer, 2005) of the urban surface.
Greenroofs are artificial environments separated from the earth by a building or another structure where plants are cultivated on a special medium (Osmundson, 1999). Among many other advantages over conventional roofs, such technique greatly reduces the effects of heating (Vecchia, 2005). After over 30 years of testing and improvements, the Modern Extensive Greenroof (MEG) system has become the most internationally used technique to construct greenroofs in temperate regions (Köhler and Poll, 2010). Although problems with this 
technique are likely uncommon, they are usually difficult to solve due to the complex six-layered structure of MEG roofs (Thuring and Dunnett, 2014): Waterproofing membrane, root barrier, drainage, filter, water storage and growing medium (soil or substrate). The system therefore has a high installation and maintenance cost (Wong et al., 2003) which may prevent its widespread application, especially in developing countries.

Another limiting factor for tropical greenroof implementation is plant survival. Plant selection and testing for greenroof applications have taken place mainly in temperate climate (Dunnett and Nolan, 2004; Durhman et al., 2006; Dunnett et al., 2008; Getter and Rowe, 2008; 2009; Getter et al., 2009; Lundholm et al., 2010), with a set of conditions that are radically different from those of the hot-humid tropics (Tan and Sia, 2009). A more encompassing literature (Silva, 2016) provides more information on greenroof advantages and comparisons between tropical and temperate greenroofs. The general lack of scientific knowledge about the flora capable of surviving in stressful conditions (e.g., high solar irradiance, drought, heat) prevailing on greenroofs installed in tropical climate (Laar and Grimme, 2006; Parizotto and Lamberts, 2011) turns the biological component, especially the choice of plant species, the main aspect for the success in these regions.

The Earth's 35 recognized "biodiversity hotspots" host $77 \%$ of the world's endemic flora (Mittermeier et al., 2011). Considering that several of these hotspots are located in the tropics, making such "biological capital" into a protagonist in an extremely rich source of plant material that can be tested for greenroof implementation under tropical conditions. Thus, epiphytes from tree canopies (Benzing, 1990), lithophytic species from inselbergs (Porembski and Barthlott, 2000) and psammophilous species from sand coastal dunes (Mantovani and Iglesias, 2005; 2010) can be valuable due to their adaptations to harsh tropical abiotic conditions.

Innovative approaches are required to further the adoption of greenroof installations in tropical climates, which includes minimizing the complexity and cost of this technique. The reduction in complexity should be followed by a careful selection of cultivated plants suited to grow under the stressful conditions prevailing on tropical rooftops. In the present study, our objective is to describe in detail a new greenroof technique and its implementation, to compare its initial financial costs with the leading MEG technique and to evaluate its influence on physiological plant performance of this extreme-adapted flora. The proposed new technique suits extensive and semi-intensive (Magill et al., 2011) greenroofs under tropical conditions, enabling lower-cost and accessible (Dunnett et al., 2008) installations that, as such, is applicable on low income houses in urban areas of the developing world.

\section{Materials and Methods}

\section{Experimental Tropical Greenroof}

Experiments were performed on a an actual occupied house rather than on a dimensionally reduced rooftop or greenhouse grown module which are typically used in studies of this subject (Oberndorfer et al., 2007; Laar et al., 2001; Simmons et al., 2008; Farrell et al., 2012; 2013).

The proposed new method is based upon simplifications of available technologies, using the MEG technique as a starting point (Thuring and Dunnett, 2014). The system consists of a new substrate-free greenroof technique comprising only three layers from the structural roof top: Thin geotextile, waterproofing membrane and thick geotextile, which are half of the MEG number. The drainage, root barrier and substrate layers that are used in MEG were removed.

The experimental tropical greenroof was installed in December 2012 , on a single family house at Niterói, Rio de Janeiro State, Brazil (lat. $22^{\circ} 55^{\prime} \mathrm{S}$, long. $42^{\circ} 58^{\prime} \mathrm{W}$, alt. $150 \mathrm{~m}$ ). The $250 \mathrm{~m}^{2}$ rooftop was completely covered with the three layers and included an overhead irrigation system (Fig. 1) and pathways.

The structural roof is distributed in two $10 \%$ inclined planes with north and south water flow directions and consists of pre-molded steel reinforced concrete pieces intercalated with ceramic bricks covered by steel reinforced concrete. Viapol ${ }^{\circledR}$ brand additive was added to the top concrete layer for waterproofing, followed by Sikatop $108^{\circledR}$ brand of superficial sealer for additional waterproofing. The first layer applied was a RT 10 (10 $\mathrm{KN}$ rip tension) geotextile (Bidin ${ }^{\circledR}$ brand) directly over the smoothed concrete mortar and along the water flow directions. This caused a soft base to be formed for the installation of the waterproofing membrane, avoiding any sharp tips that could damage it. Joining of linear parts was done by using a hot air thermo-welding machine. The second layer was a $0.8 \mathrm{~mm}$ thick waterproofing PVC membrane $\left(\right.$ Vinilona ${ }^{\circledR}$, Sansuy ${ }^{\circledR}$ company) associated with geotextile (top side) that was installed with pieces perpendicular to the water flow directions. Joining of linear parts was done by thermowelding with the addition of PVC glue. Over that, the third and final layer was a RT 16 (16 KN rip tension) geotextile $\left(\right.$ Bidin $\left.^{\circledR}\right)$ that was laid along the water flow directions (perpendicular to the waterproofing membrane orientation) acting as the rooting media. Sections were glued together with a polyurethane construction adhesive, since thermal welding could damage the waterproofing membrane below (Fig. 2). This layer functions as a rooting medium, enabling water to flow by capillarity between its polyester fibers, thus characterizing a soilless horticultural system that functions in a similar way to an ebb and flood hydroponic system with rooting on synthetic fibrous materials (Logendra and Janes, 1997). 


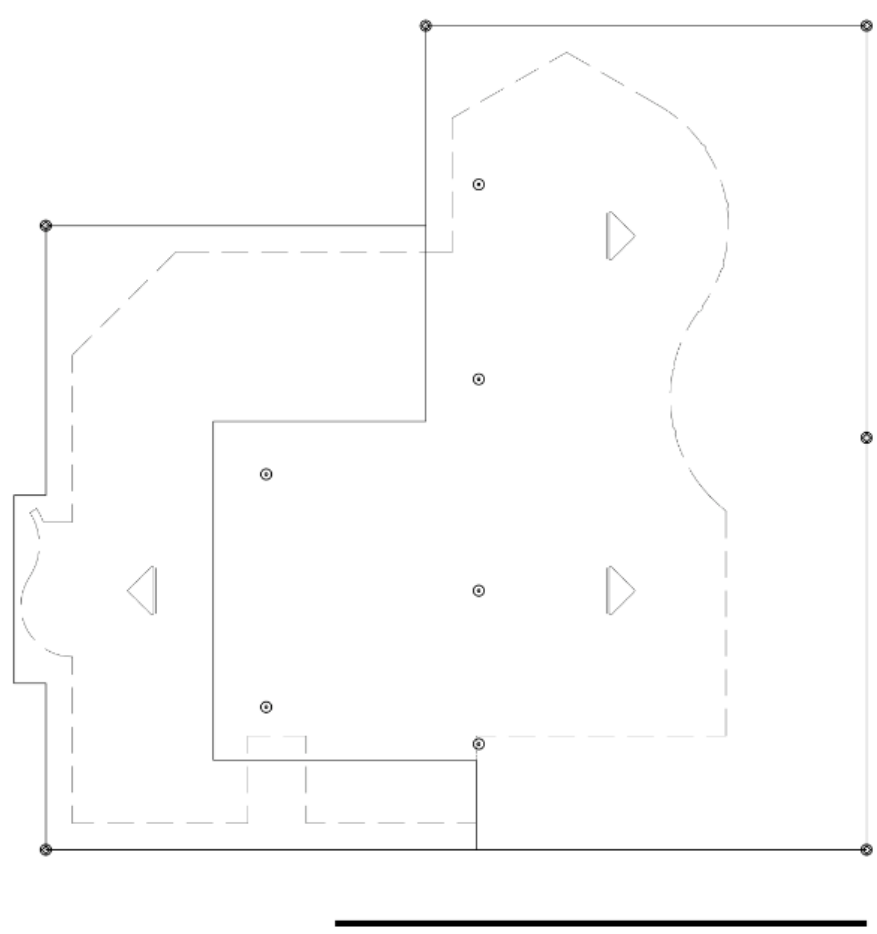

Fig. 1: Roof plan (solid line) of a single-family house designed for the installation of an experimental tropical greenroof technique, which consists of three layers: Thin geotextile, waterproofing membrane and thick geotextile. Arrows indicate directions of water flow and dashed lines indicate external walls. Roof total area is $250 \mathrm{~m}^{2}$. Irrigation sprinkler positions are indicated by and Project was installed at Niterói municipality, Rio de Janeiro State, Brazil in December 2012

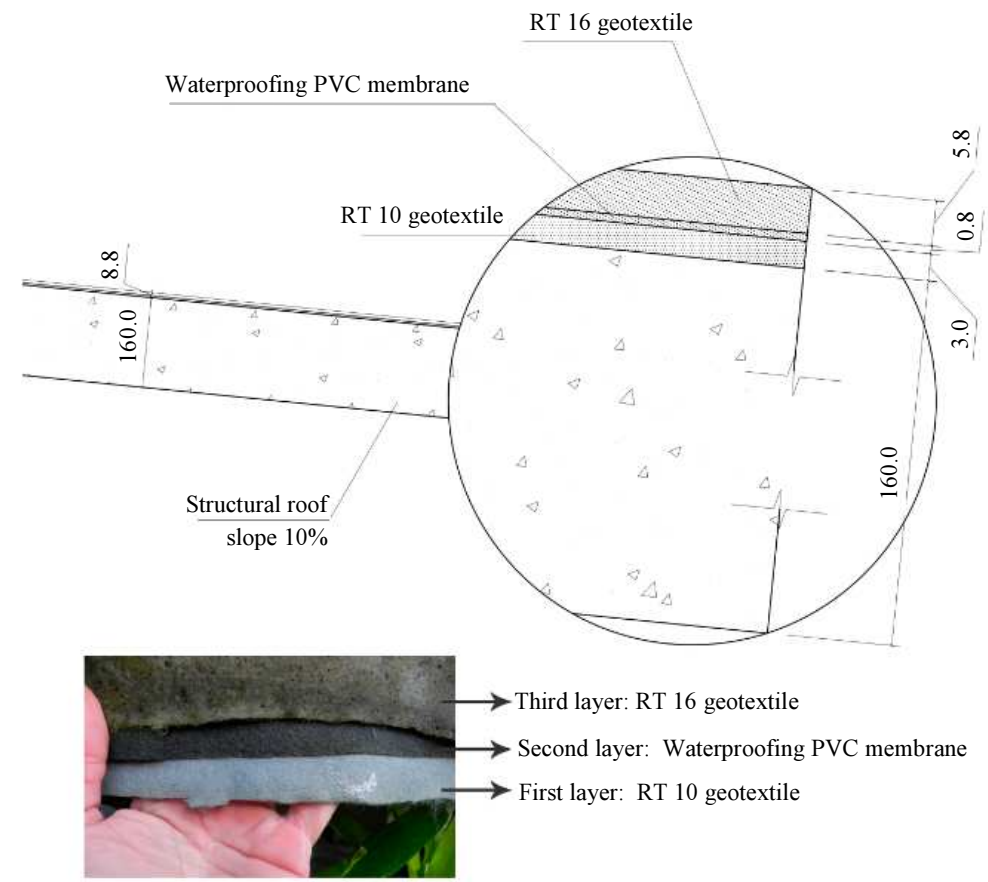

Fig. 2: Detailed roof cross section of a three layered tropical greenroof technique. Cross section of roof covered by the three layers that are responsible for waterproofing and rooting media (all dimensions in $\mathrm{mm}$ ) and picture of the three layers 
A $10 \mathrm{~cm}$ edge of the three layers covered the roof perimeter and was left beyond the thickness of the concrete slab in order to any excess water drips into the water collecting gutter for reuse (Fig. 3), plus avoiding any backwash. The pathways were installed by fixing 130 granite stone slabs (aprox. $40 \times 40 \mathrm{~cm}$ ) using sand and Portland cement mortar. Stones were installed leveled and diagonally oriented along the water flow directions, in order to avoid interrupting the water flow and creating undesirable water retention upstream and dry bands downstream. A very small amount (ca. $20 \mathrm{Kg}$; $0.08 \mathrm{~kg} / \mathrm{m}^{2}$ ) of natural soil from the nearby forest was crushed and evenly spread over the entire geotextile surface to maximize fungi and bacterial biodiversity (Brenneisen, 2006; McGuire et al., 2013).

\section{Financial Analysis}

Material and installation costs to the proposed technique for tropical greenroofs were estimated in order to be compared with MEG widespread technique. A MEG related technique was budgeted for a tropical scenario, contemporarily, by Rosseti et al. (2013). To maintain the reference for the estimated values, costs were presented in American dollars. The rate of $\mathrm{R} \$$ 2.10/1 US\$ for December 2012, was used to convert costs (Source: Banco Central do Brasil).

\section{Biodiversity at the Experimental Greenroof}

A sparse initial planting started on January $2^{\text {nd }}$ and finished on March $31^{\text {st }}$ of 2013 . It consisted of 230 species belonging to 20 plant families comprising native and exotic taxa. Species habit was classified following IUCN red list (2017). The high taxonomic diversity tested aimed to establish a broad list of greenroof candidate species for the tropics (Tan and Sia, 2009) under the new proposed technique. Species were selected according to similarity of the roof abiotic conditions as well as native environmental parameters and availability of saplings. Smaller plants were simply laid directly on the superficial geotextile layer (Fig. 4) and larger ones were fastened in place with ceramic bricks until rooting took place. Species with pendant growth were introduced along the roof edges by attaching them to the irrigation pipes.

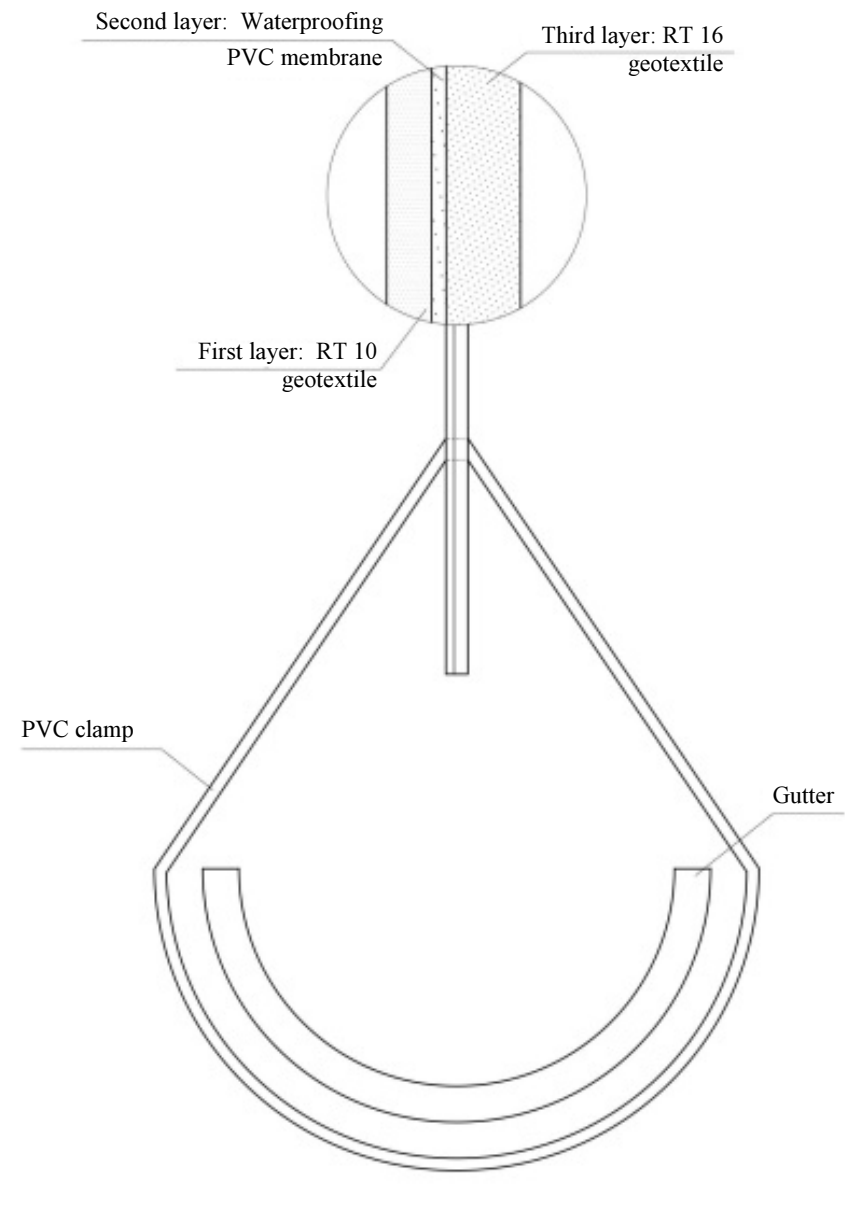

Fig. 3: Specially developed gutter attached to hanging edge of the three layers 


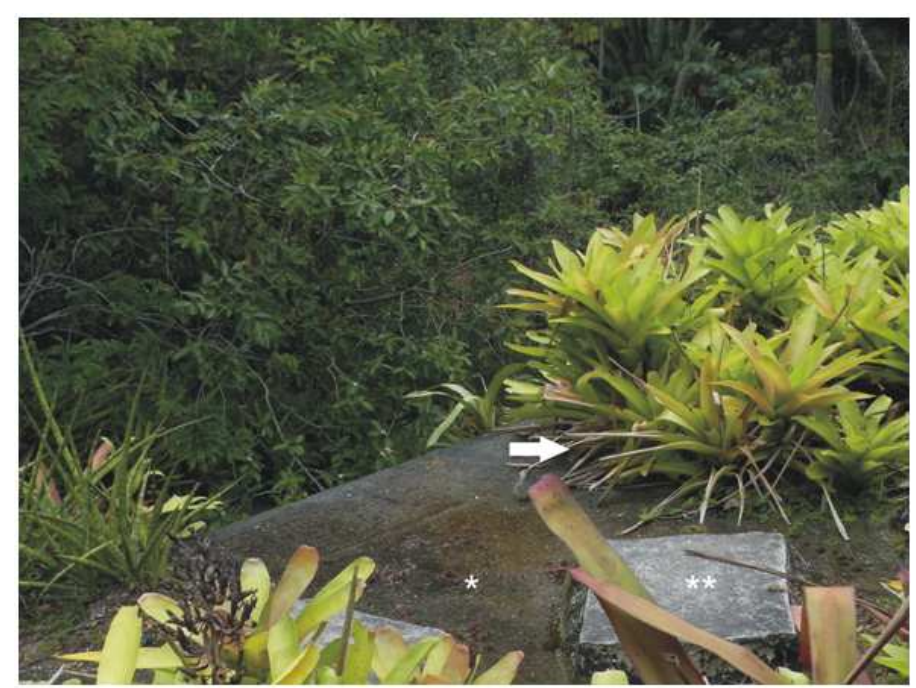

Fig. 4: Tropical greenroof showing Brazilian native bromeliad Neoregelia compacta (arrow) planted directly on the $3^{\text {rd }}$ layer $(*)$ superficial (RT 16 geotextile). Greenroof was installed as an experimental low cost and simplified three-layer technique, note stone paths $(* *)$

The majority of introduced plant families is succulent and has CAM photosynthetic metabolism, as both parameters offer resistance to high temperatures and to periodical drought (Lüttge, 2004). However, C3 plant species were also used. This diversified initial planting followed literature recommendation (Köhler, 2006) in order to improve plant survival (Nagase and Dunnett, 2010; Wolf and Lundholm, 2008) and greenroof services, such as runoff and temperature reductions (Lundholm et al., 2010).

Conservation of endangered species is a positive consequence of greenroof (Köhler, 2006). Whenever available, these species were also introduced following IUCN red list (2017), Martinelli and Moraes (2013), Tropicos database (2016), CNC Flora (2015) or CITES (2016).

\section{Maintenance of the Experimental Tropical Greenroof}

Maintenance of the proposed greenroof involved irrigation and plant invasion control. Vegetation maintenance was done by controlling introduced plant growth to avoid overgrowing among individuals and manually removing invasive colonizing species (e.g., Cyperus rotundus). Occasional plant material substitution was needed during the initial phase of installation until plant acclimation was achieved.

Overhead irrigation was chosen because of its greater efficiency for greenroofs (Rowe et al., 2014) and was applied shortly after sunset on days without precipitation. Irrigation was done via six internal Rainbird $^{\circledR} 360^{\circ}$ spray heads and six external Rainbird ${ }^{\circledR}$ 2045-PJ-08 impact sprinklers located on the corners
(Fig. 5). The average volume input was $20 \mathrm{~L} / \mathrm{min}$ and the irrigation remained on for about 15 minutes on average. Thus, about $300 \mathrm{~L}$ of water was consumed in every irrigation event. The irrigation system had to be kept unclogged and to deliver even amounts of water. This irrigation schedule keeps the rooting media periodically humid and bromeliad tanks partly filled, since these take a few days without precipitation to become completely empty (Zotz and Thomas, 1999).

Even without specific root barrier the growth of superficially rooting species presented no root penetration into the structural roof or any detectable puncture over the three year period on the Sansuy ${ }^{\circledR}$ Vinimanta waterproofing membrane that had a five year warranty against leaks. The weeding frequency was about once every three months, took about three manhours to be completed and was compatible with the maintenance required for roofs on the same region commonly covered by ceramic tiles.

\section{Plant growth and Morphophysiology}

A method based upon DIA (digital image analysis) (Sendo et al., 2010; Barker and Lubell, 2012) was used in order to evaluate plant horizontal coverage for nine selected species. A digital Nikon Coolpix P100 camera set to 10 Mpixels resolution was connected to a tripod facing directly downwards. Photographs of fixed positions were repeated weekly during the establishment period from March $31^{\text {st }}$ to April $6^{\text {th }}$, 2013. Images were analyzed using ImageJ program, following Sendo et al. (2010), in order to calculate coverage area, data being log transformed prior to graphing (Niklas, 1994). 


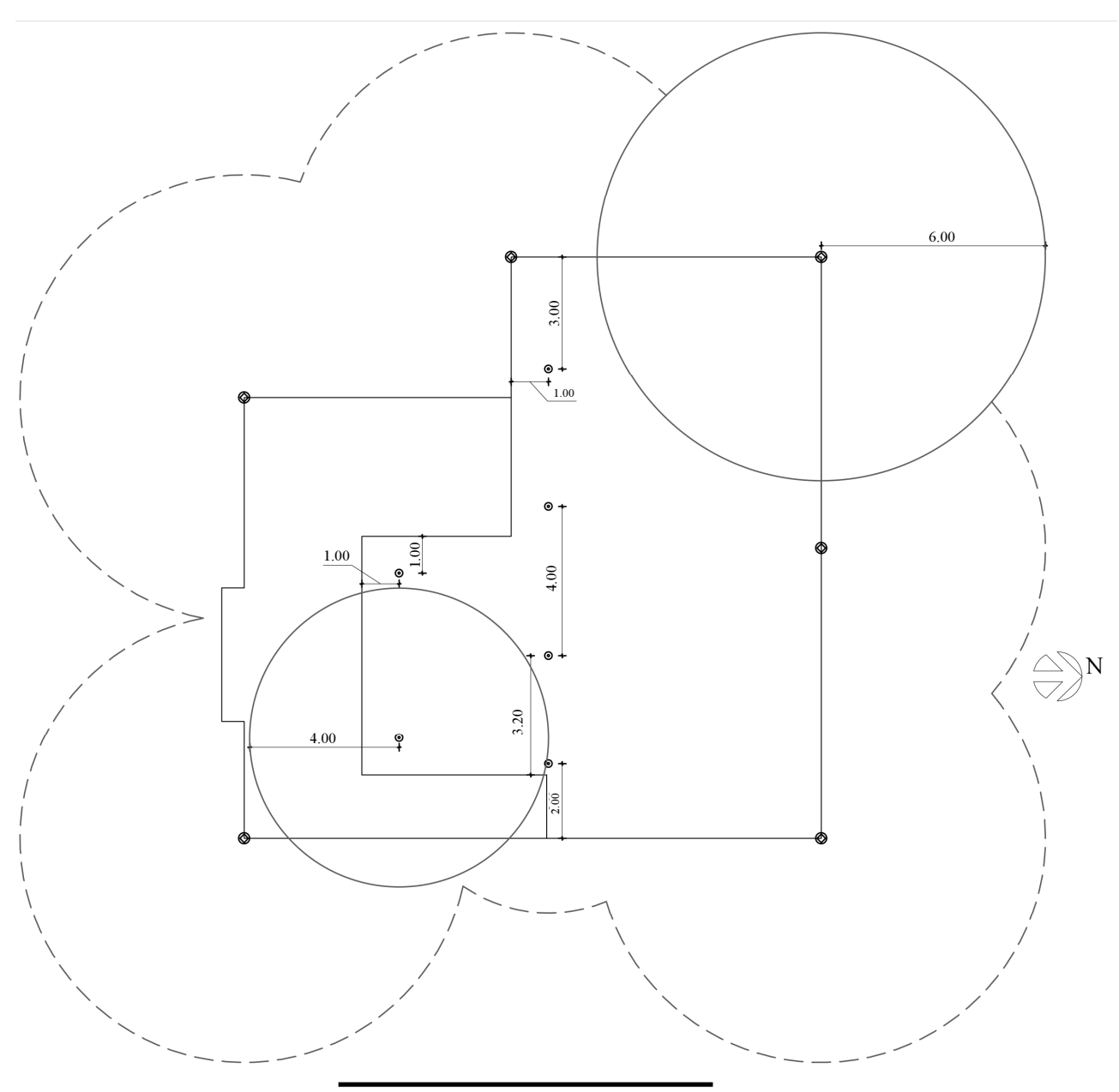

Fig. 5: Irrigation sprinkler positions indicated by and and action radius covering entire roof indicated by circles. For clarity, dashed lines represent external perimeter of watering

Plant morphophysiological parameters were used to characterize the flora after three years of cultivation under the newly proposed greenroof technique. Leaf succulence improves water storage and thermal stability and was evaluated following Mantovani (1999). Circular leaf sections, which were obtained with cork borers, were kept moistened with humidified filter paper under dark conditions and under $7^{\circ} \mathrm{C}$ for $24 \mathrm{~h}$ in order to maximize fresh weight. Posteriorly, leaf specimens were dried until constant weight under $60^{\circ} \mathrm{C}$. Fresh and dry weights were determined on a $0.001 \mathrm{~g}$ Ohaus precision balance. Succulence was quantified by the ratio (maximum fresh weight-dry weight)/leaf area.

Leaf physiological status of greenroof plants was also evaluated by its efficient photosynthetic quantum yield capacity obtained via a chlorophyll fluorescence analysis under light adapted conditions (Genty et al., 1989). Fluorescence is adequate to provide insights into the ability of plants to tolerate environmental stresses and into the extent to which those stresses have damaged the photosynthetic apparatus (Maxwell and Johnson, 2000). Genty's yield parameters were determined through a modulated Pulse Amplitude fluorometer (MINI-PAM, H. Walz, Effeltrich, Germany) during dawn (6:00 to 7:00), before the incidence of direct sunlight and also during the afternoon (13:30 to 14:30) when plants were subjected to high Photosynthetic Photon Flux Density (PPFD) conditions surpassing $1,800 \mu$ moles $\mathrm{m}^{-2} \mathrm{~s}^{-1}$. We stated that overall conditions under the new greenroof technique were sufficient for plant survival under non photoinhibitory conditions. Therefore, yield parameters collected at dawn should be higher than 0.7 (Genty et al., 1989).

\section{Statistical Analyses}

Normal distribution of data was evaluated by the Kolmogorov-Smirnov (K-S) test and homogeneity of variances was evaluated by the Levene test. Succulence comparisons among families were performed using 
One-way ANOVA. Genty's Yield comparisons among families and day time were performed using respectively One-way ANOVA and Paired t-test $(p<0.05$; Zar, 1996). Multi pairwise comparisons were performed using Tukey test.

Plant growth per species was compared through linear ordinary regressions fitted for log transformed data $(\log$ of area value +1$)$. Differences in growth rates were detected by comparing the angular coefficients (i.e., scaling exponent, $\alpha$ ) (Niklas, 1994), using Standardized Major Axis Tests and Routines (SMATR) (Warton et al., 2006).

Both succulence and chlorophyll fluorescence parameters were measured respectively for 114 and 156 species belonging to 14 botanical families. The objective was to compare and detect potential plant families whose species could be better suited to be grown under the new greenroof technique proposed. Regarding succulence, the measurement of three individuals was used to represent each species. Subsequently, at least three species were used to obtain the mean value for family category, except for Araceae, Clusiaceae, Euphorbiaceae and Pandanaceae which were represented by only two species, while just one species was evaluated for Asteraceae. As for the quantum yield parameter, the same procedure was done to obtain mean value for each family category. Other than for Araceae, Clusiaceae, Melastomataceae and Pandanaceae, all other families were represented by at least three different species. Moreover, quantum yield was measured twice a day, at 06:00 and 14:00, to obtain mean values for the daytime category. Yield variation along the day was used to evaluate photoinhibition recover.

Statistical procedures were performed using Statistica software. Significance was assumed at $p<0.05$ (Zar, 1996).

\section{Results}

\section{Financial Analysis}

The installation of the newly proposed greenroof system in three layers cost US\$ $31.84 / \mathrm{m}^{2}$. Of these, the largest investment $(52 \%)$ was related to the waterproofing membrane, followed by the acquisition and planting of vegetation $(22 \%)$. The remainder of the cost involved manpower and geotextile purchase (4.5 and $6.5 \%$ each item, respectively) (Table 1 ).

In order to compare the proposed technique with costs of available greenroof installations, data from a contemporary study was analyzed (Rosseti et al., 2013), which dealt specifically with the Brazilian economic scenario. Disregarding the structural roof, the final cost for the greenroof installations found by these authors was US\$ $71.20 / \mathrm{m}^{2}$. Costs for the experimental greenroof, when keeping the same values for the vegetation found by these authors, are presented in Table 1. The proposed technique is $56 \%$ lower in total cost when compared to Rosseti et al. (2013).

\section{Biodiversity at the Experimental Greenroof}

The growth of vegetation at the newly proposed technique was followed for three consecutive years. An artificial plant community (Fig. 6) with high diversity established itself on the roof, taking two years to achieve full coverage (Fig. 7a-7e).

Of the approximately 230 species and cultivars (hybrids and horticultural varieties) initially introduced, a total of 218 species belonging to 20 botanical families not only survived, but grew and flowered on the experimental green roof (Appendix 1). The distribution of families displays a strong predominance of Bromeliaceae and Cactaceae with 38 and $21 \%$ of the total diversity, respectively. Followed by Orchidaceae (6\%), Apocynaceae (4\%), Euphorbiaceae (2\%), Araceae (2\%), Melastomataceae (1\%), Clusiaceae (1\%) and Amaryllidaceae (1\%). In the selected families $64 \%$ are monocots and $35 \%$ are dicots and only $1 \%$ ferns. The exotic families are mentioned separately: Asparagaceae (9\%), Crassulaceae (3\%) and Xanthorhoeaceae (3\%).

Concerning growth forms, the diversity is distributed as: Herbs with $49 \%$; succulents (34\%); large shrubs $(5 \%)$; small trees (4\%); succulent shrubs (3\%); vines $(3 \%)$; succulent trees $(1 \%)$; small shrubs $(0.5 \%)$ and hydrophytes (aquatics) in bromeliad tanks $(0.5 \%)$. As for the habit, we found a strong predominance $(63 \%)$ of epiphytes $(29 \%)$, lithophytes $(23 \%)$ or both $(11 \%)$. Besides these, other species adapted to multiple substrates add up a significant $30 \%$, such as lithophyte or terrestrial $(26 \%)$ and epiphyte or terrestrial $(3 \%)$ and lithophyte, epiphyte or terrestrial (1\%). Finally, 5\% are terrestrial and $2 \%$ psammophilous.

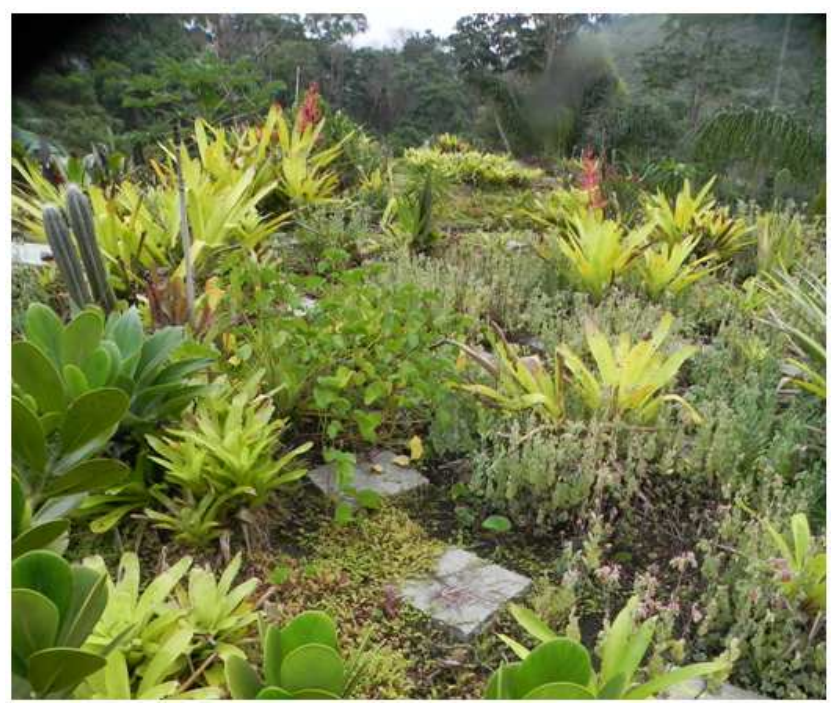

Fig. 6: Established plant community, May 2015 

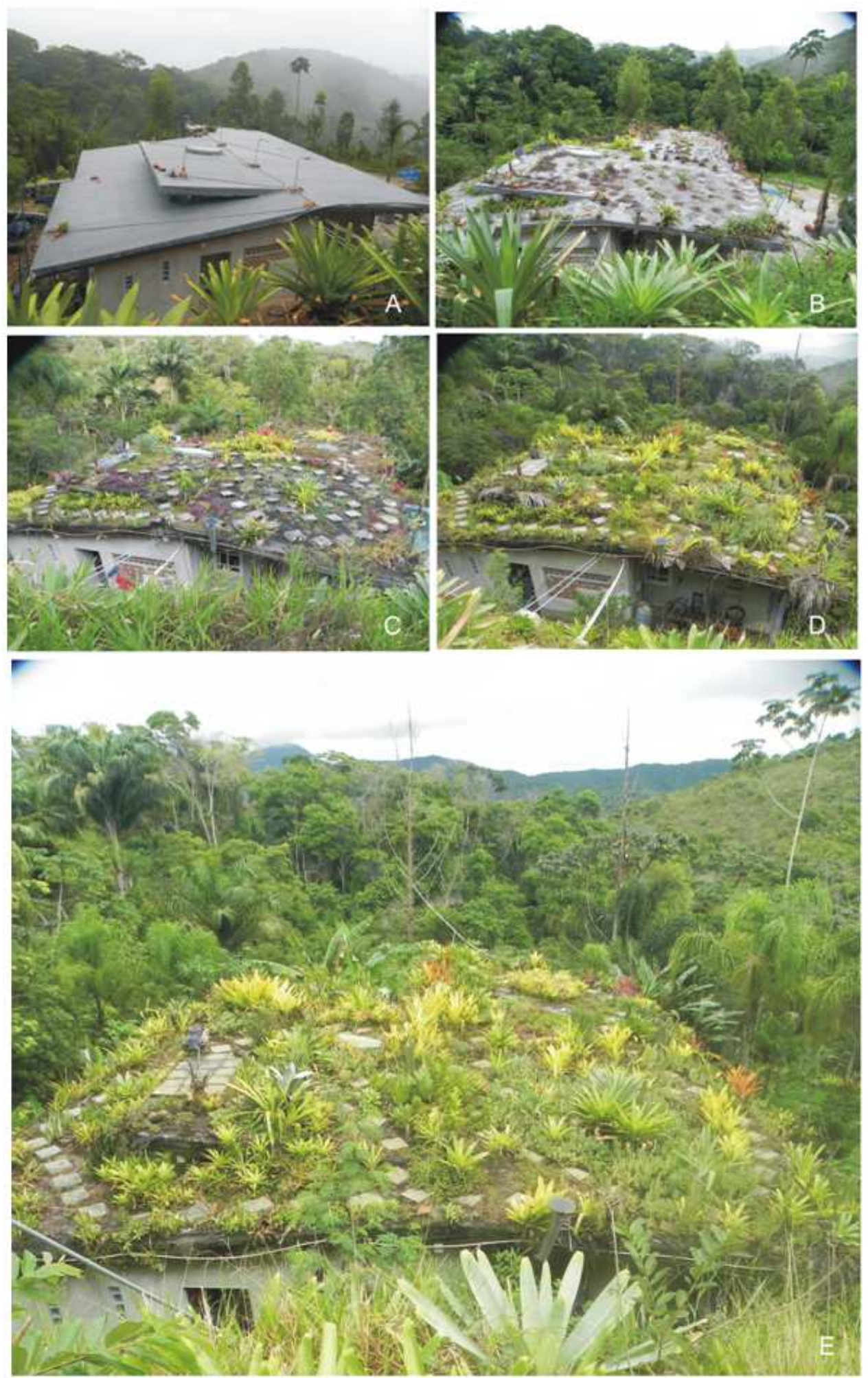

Fig. 7: Cronosequence of a tropical greenroof installation in Southeastern Brazil. A. Greenroof with three layers (thin geotextile, waterproofing membrane and thick geotextile) recently installed without vegetation-December 2012. B. Early planting of tropical species-March 2013. C. Steady clonal growth-October 2013. D. Established artificial community fully covering the roof area-May 2015. E. Artificial tropical greenroof community that has become stable on the long term-March 2016 
Table 1: Financial costs for installation of a tropical greenroof in three layers estimated for a $250 \mathrm{~m}^{2}$ roof area. Note that the cost of the waterproofing membrane includes its installation

\begin{tabular}{|c|c|c|c|}
\hline Item & Quantity & Total price & Cost per $\mathrm{m}^{2}$ \\
\hline RT 10 geotextile & $253 \mathrm{~m}^{2}$ & US\$ 410.82 & US\$ 1.62 \\
\hline RT 16 geotextile & $253 \mathrm{~m}^{2}$ & US\$ 545.76 & US\$ 2.16 \\
\hline $0.8 \mathrm{~mm}$ thick water & $283.14 \mathrm{~m}^{2}$ & US\$ $4,991.76$ & US\$ 17.63 \\
\hline Proofing PVC membrane & & (installed) & \\
\hline Vegetation & Aprox. 5 seedlings $/ \mathrm{m}^{2}$ & US\$ $1,678.57$ & US\$ 7.14 \\
\hline $\begin{array}{l}\text { Labor for installing RT } 16 \\
\text { geotextile and planting }\end{array}$ & $\begin{array}{l}80 \text { hours-man at } \\
\mathrm{R} \$ 8.75 / \mathrm{h}\end{array}$ & US\$ 333.33 & US\$ 1.42 \\
\hline Total Cost (US dollars) & & & US\$ 7,960.25 \\
\hline$\left(\operatorname{Cost} / \mathrm{m}^{2}\right)$ & & & US\$ $31.84 / \mathrm{m}^{2}$ \\
\hline
\end{tabular}

Regarding the origin of the diversity present, most species $(51 \%)$ are native from Brazil, of which $40 \%$ are endemic and only $11 \%$ also occur in other countries. On the other hand, exotics are also expressively represented, with $42 \%$ of the total, mostly from Mexico, South Africa and Madagascar. Only $7 \%$ are not natural species, or were developed artificially in the form of hybrids $(2 \%)$ or cultivars (5\%). It is important to stress that a significant contribution to diversity comes from the cultivation of pendulous growing species in the eaves, especially the north and south ones. These individuals are exposed to higher substrate moisture due to the roof slope, representing $28 \%$ of total diversity, compared to $66 \%$ for species restricted to the roof itself and only $6 \%$ in both situations. In terms of conservation of rare or endangered species, $3 \%$ are evaluated as critically endangered, $8 \%$ are endangered and $4 \%$ vulnerable. A table listing the diversity grown on the experimental greenroof and supplementary information is presented in Appendix 1.

\section{Plant Growth and Morphophysiology}

All plant species analyzed were able to increase the initial surface area covered along 10 weeks $\left(\mathrm{R}^{2}=0.82\right.$ to $0.96 ; \mathrm{p}<0.001)$. The only exceptions were Agave gypsophylla and Neoregelia concentrica, with surface area increasing just during the last two weeks of monitoring. The species studied differed in relative growth along the experiment which lasted over two months, as indicated by multiple comparison of slopes $(\mathrm{P}$ $=0.023$ to 0.0001). The highest coverage rate was presented by Callisia repens, which more than tripled the coverage compared to the starting area (Fig. 8a-8c), with an average rate growth of about $500 \mathrm{~cm}^{2} /$ week.

The closely related Callisia fragrans and Callisia warszewicziana showed lower growth rates, from about 5 to $20 \mathrm{~cm}^{2} /$ week. Tradescantia pallida and Tradescantia zebrina were also steady and relatively fast growers, the first at about $40 \mathrm{~cm}^{2} /$ week and the second showing occasional dormant periods followed by prompt recoveries varying from 10 to 40 $\mathrm{cm}^{2} /$ week. Kalanchoe fedtschenkoi, on the other hand, raised its covered area by 1.5 times over the same period, showing growth rates around $7 \mathrm{~cm}^{2} /$ week. The species of bromeliad Neoregelia concentrica hardly increased coverage: Only 0.04 times. Echeveria gibbiflora showed variable growth around 10 $\mathrm{cm}^{2} /$ week (Fig. 9).

Succulence and quantum yield values obtained by chlorophyll fluorescence are shown by botanical family (Fig. 10). The largest succulence value was found for the stem of Opuntia ficus-indica (Cactaceae), over $19,000 \mathrm{~g} / \mathrm{m}^{2}$. Most of the species studied, however, were evaluated for leaf succulence, which ranged from $203.24 \mathrm{~g} / \mathrm{m}^{2}$ (Philodendron warszewiczii, Araceae) to $15,296.49 \mathrm{~g} / \mathrm{m}^{2}$ (Senecio crassissimus, Asteraceae). In terms of family averages, the smallest and highest values of leaf succulence were $217.10 \mathrm{~g} / \mathrm{m}^{2}$ and $6,876.72 \mathrm{~g} / \mathrm{m}^{2}$ respectively for Araceae and Xanthorrhoeaceae. The Bromeliaceae and Orchidaceae families had average succulences of $989.75 \mathrm{~g} / \mathrm{m}^{2}$ and $1,394.91 \mathrm{~g} / \mathrm{m}^{2}$, respectively. Regarding percentages, $20 \%$ of the taxa had succulence values below $500 \mathrm{~g} / \mathrm{m}^{2}$, $53 \%$ from 500 to $2,000,18 \%$ from 2,000 to 5,000 and only $9 \%$ above $5,000 \mathrm{~g} / \mathrm{m}^{2}$.

The photochemical quantum yield was measured over two periods of the day, morning and afternoon, when the intensity of light levels with photosynthetic capacity exceeded $1,800 \mu \mathrm{mol} \mathrm{m} \mathrm{m}^{-2} \mathrm{~s}^{-1}$. Dawn and dusk values were significantly different (Paired t-test $p<0.05$ ) for the families shown on Fig. 11. The vast majority of quantum yield values (expressed by Genty`s parameter) were above 0.7 during the morning (Fig. 11), except for some species, for example: Alocasia 'Amazonica' (Araceae); Chamaedorea seifrizii (Arecaceae); Sansevieria 'Alva', Sansevieria ehrenbergii (Asparagaceae); Aechmea amicorum, Aechmea cefaloides and Aechmea pectinata (Bromeliaceae) with values from 0.55 to 0.68 . However during the afternoon all species had a strong and significative $(p<0.05)$ reduction in yield, with values even lower than 0.4 , except for Clusiaceae with yield values at dusk around 0.66. Extreme cases have been shown by species Pitcairnia sp. 1 (Bromeliaceae) and Heterocentron elegans (Melastomataceae) with values reduced to 0.21 and 0.18 . 


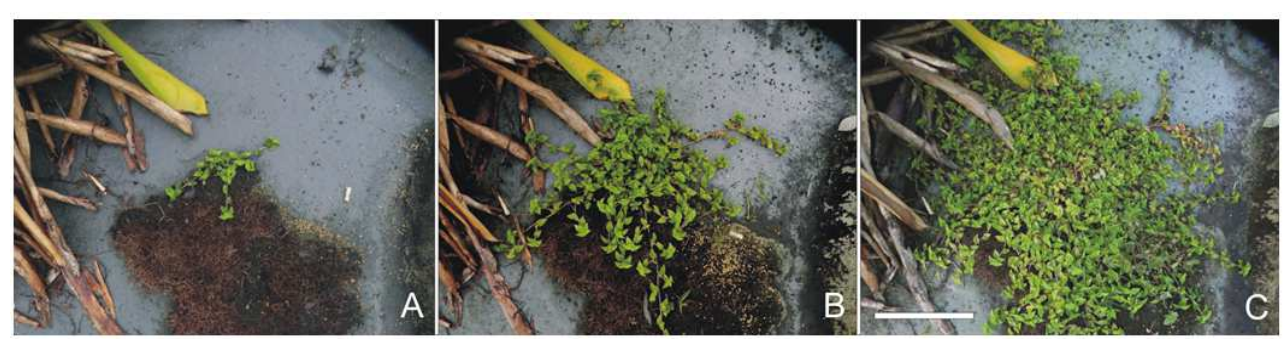

Fig. 8: Growth of Callisia repens on top of a tropical greenroof installed in southeastern Brazil. Photographs were taken at the same position and were used to estimate growth rate through covered area. A. One week of growth. B. Five weeks of growth. C. Ten weeks of growth. Scale bar equals $20 \mathrm{~cm}$

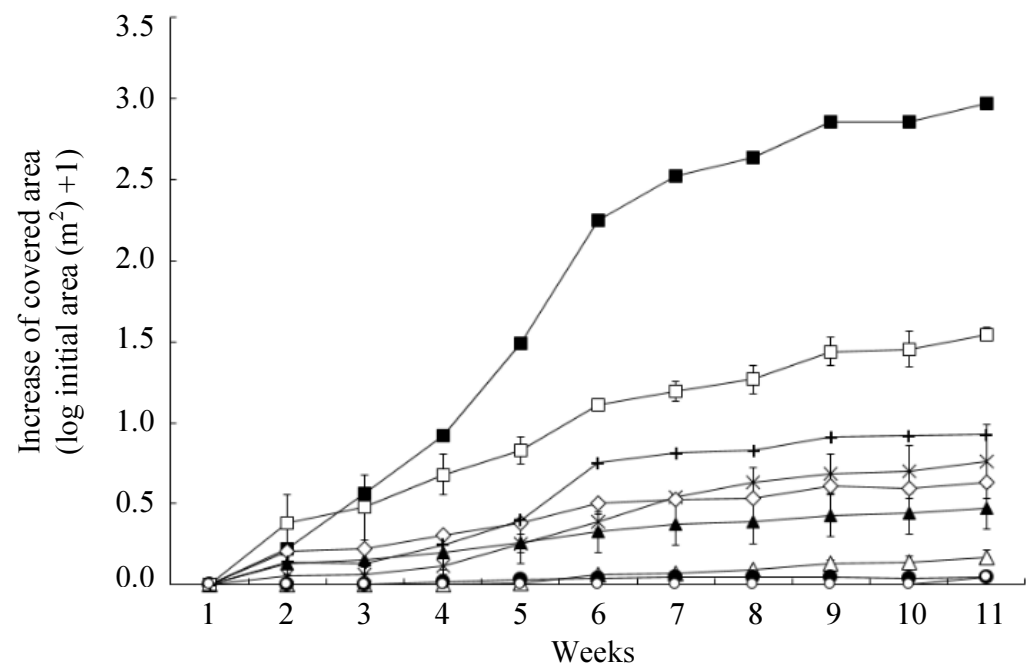

Fig. 9: Surface coverage exhibited by eight different plant species over 10 weeks. Data are related to the initial area covered on the first day of the experiment. Bars indicate standard deviation. Symbols: (ロ) Callisia repens; $(\square)$ Kalanchoe fedtschenkoi; $(+)$ Callisia warszewicziana; $(\times)$ Callisia fragrans; $(\diamond)$ Tradescantia pallida; $(\mathbf{\Delta})$ Echeveria gibbiflora; $(\Delta)$ Tradescantia zebrina; ( $)$ Agave gypsophylla; (•) Neoregelia concentrica; ( $\mathrm{n}=1$ to 3 patches)

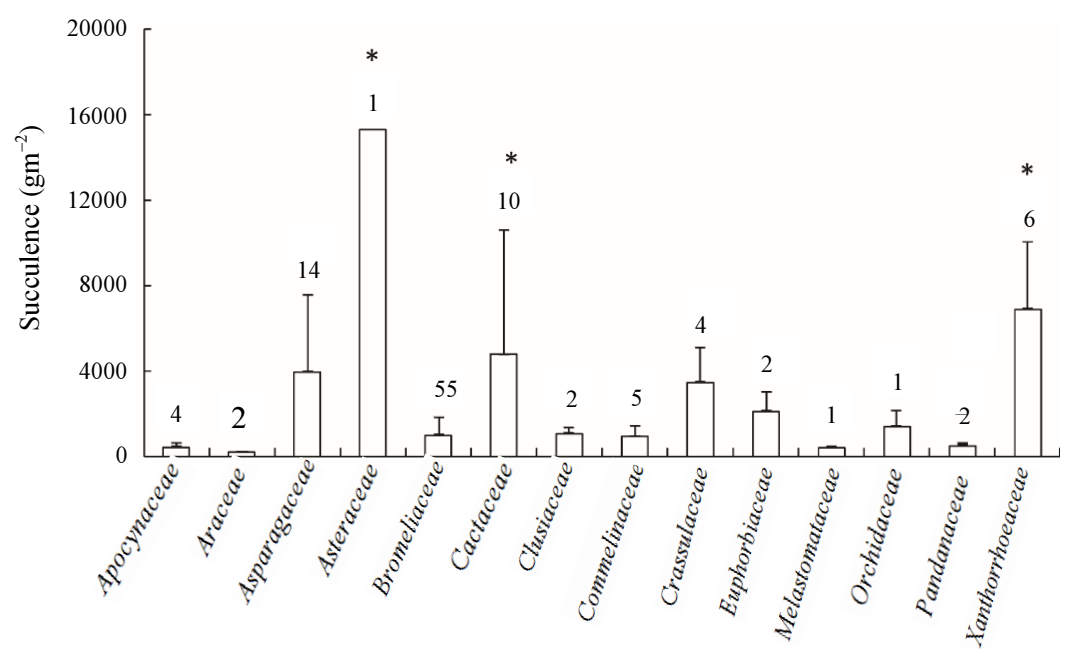

Plant families

Fig. 10: Succulence for 114 species of vascular plants belonging to 14 different plant families growing after three years on the proposed Tropical Greenroof. Succulence is presented by bars for average of each botanical family and dashed line for standard deviation. Number of species per family is indicated above respective bar. Asterisk indicate significant difference $(p<0.05)(\mathrm{n}=3$ for each plant species) 


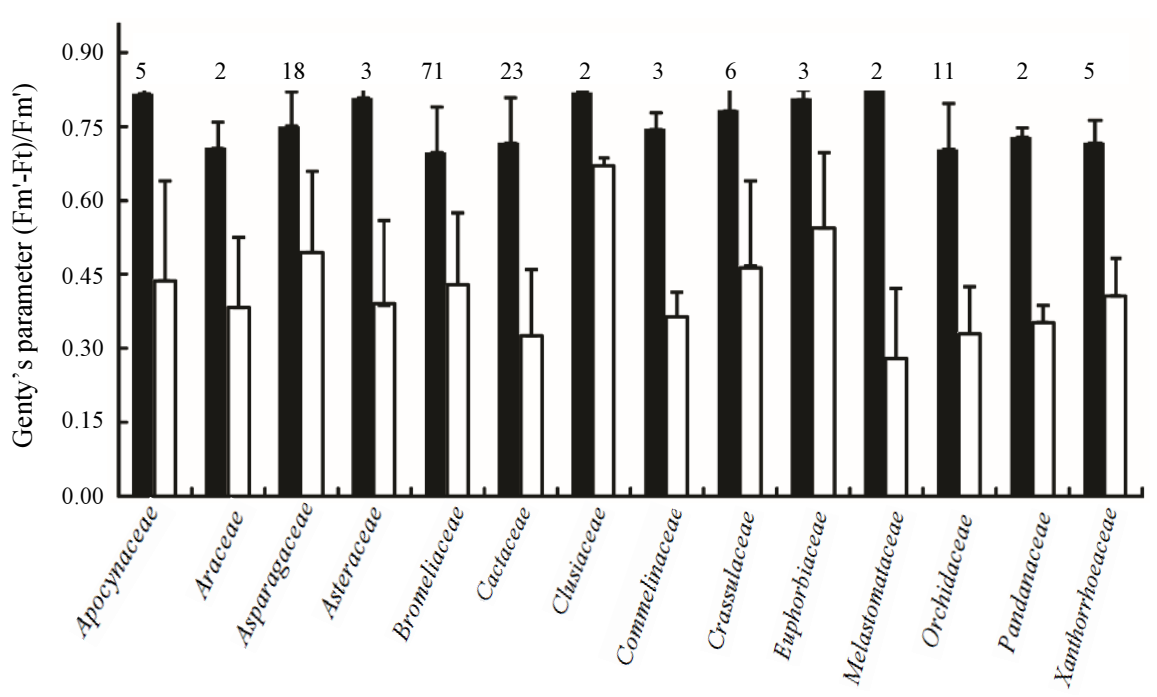

Plant families

Fig. 11: Photochemical properties for 156 species of vascular plants belonging to 14 plant families growing after three years on the proposed tropical greenroof. Photochemical yield (Yield ((Fm'-Ft)/Fm') measured in the morning (black bars) and afternoon (white bars). Data are presented by bars for average of each botanical family and dashed line for standard deviation. Number of species per family is indicated above respective bar. ( $\mathrm{n}=3$ for each plant species)

\section{Discussion}

Previously, greenroofs were built for leisure and aesthetics. Yet, currently, a much more practical approach has prevailed (Henry and Frascaria-Lacoste, 2012), focusing mainly on rainfall management and reduction of energy (Fioretti et al., 2010). The new greenroof technique presented here is comparatively less complex and costly than MEG, besides sustaining growth of native and exotic plants under tropical conditions. Comparing with MEG, the absence of the drainage layer was counterbalanced by an inclined structural roof. In spite of not having a specific root barrier, there was no root penetration into the structural roof and no detectable puncture on the waterproofing membrane. This may have been avoided by the adequate plant choice of superficially rooting species. Additionally, the substrate layer was replaced by an ebb and flood system with rooting on the superficial geotextile.

Results of species growth and the sustained diversity demonstrate the potential for substrate-free systems to be used as a major greenroof technique under tropical climates as long as an adequate array of species is selected (Tan and Sia, 2009). The semi-intensive nature of the experimental greenroof facilitated maintenance, as well as the simplicity of extensive systems to the accessibility and the most prominent vegetation of intensive ones (Magill et al., 2011).

\section{Financial Analysis}

Establishing widespread greenroof infrastructure is essential for the manifestation of its benefits on an urban ecosystem level (Getter and Rowe, 2006; Carter and
Fowler, 2008). The life cycle analysis performed by Wong et al., (2003) showed that, after 10 years, a conventional flat roof will accumulate a greater cash input than an extensive greenroof and after 40 years it will cost down to $25 \%$ less than for the conventional roof (Clark et al., 2008). Since the initial investment is still 10 to $14 \%$ higher in a greenroof than in its conventional counterpart, a reduction of only $20 \%$ maintenance cost would demonstrate its advantages (Carter and Keeler, 2008). The new technique proposed is less than half (44.7\%) of MEG conventional greenroof technique. The lower cost has the potential to ease the implementation of widespread greenroof infrastructure, which can greatly benefit from environmental policy instruments (Carter and Fowler, 2008). These financial results, added to the potential weight reduction, reinforce the applicability for this new technique to be used as a retrofit over various kinds of pre-existing roof surfaces (Castleton et al., 2010).

\section{Biodiversity at the Experimental Greenroof}

Köhler (2006) using MEG under a temperate climate found a maximum of 64 species on a $200 \mathrm{~m}^{2}$ greenroof. Two hundred and eighteen taxa were successfully cultivated on the tropical experimental greenroof, which is a higher number even considering the reduction in complexity of the proposed technique. This indicates that a high diversity is possible, which may have been sustained by mechanisms of facilitation driven by plantplant interactions (Cook-Patton and Bauerle, 2012).

Another aspect of the high diversity introduced in the presented greenroof technique is the great variation of 
growth forms and plant sizes, amplifying niches on greenroofs (Cook-Patton and Bauerle, 2012). The fact that various growth forms (herbs, succulents, large shrubs, small trees, succulent shrubs, vines, succulent trees and small shrubs) were evenly distributed in our studied greenroof, favored plant-plant positive interactions. For example, taller specimens offer valuable shade and wind protection for smaller ones. These facilitation mechanisms are well known from extreme ecosystems such as deserts (Franco and Nobel, 1989), canopies (Nieder et al., 2001) and sand dunes (Mantovani and Iglesias, 2001).

It faces the fact that the concept of a greenroof, although artificial, is a dynamic ecosystem. Thus, it can account for the stronger performance of certain mixtures of life-forms, such as "tall forbs, grasses and succulents" found by Lundholm et al. (2010), when compared to life forms individually planted on the same greenroof system. These authors suggest that niche complementarity or facilitation mechanisms may have a strong influence on greenroof biodiversity, involving not only plants but also fauna (Brenneisen, 2006; Beatrice and Vecchia, 2011).

Similar proportions of native and exotic taxa survived the three years experiment. The survival rate is related to the fact that native species are not always the best to adapt or to be used on greenroofs and that nativeness does not, in itself, confer better ecological properties to any given greenroof (Dunnett, 2006).

\section{Plant Growth and Morphophysiology}

Success of the proposed technique was based upon plant choice from extreme lithophytic (Porembski and Barthlott, 2000), psamophyllous (Mantuano et al., 2006) and epiphytic (Benzing, 1990) habitat. Plants grown on the tropical experimental greenroof share a resistance to solar irradiance surpassing $1,800 \mu$ moles $\mathrm{m}^{-2} \mathrm{~s}^{-1}$, periodical drying of the rooting media, air temperatures higher than $40^{\circ} \mathrm{C}$, rooting media over $60^{\circ} \mathrm{C}$ and strong winds. This may be accounted for by the high frequency of CAM photosynthetic metabolism among the studied species (Kluge and Ting, 1978) which, along with elevated succulence, improves water use efficiency (Lüttge, 2004). Succulence can also generate thermal buffering capacity (Ball et al., 1988) enhancing survival under high air and leaf temperatures (Leigh et al., 2012). Other reasons are the efficient alternative mechanisms of water and nutrients absorption such as foliar trichomes and root velamen of Bromeliaceae and Orchidaceae (Benzing, 1990), respectively, accounting for $42 \%$ of the diversity. These factors contribute to the complete greenroof coverage in approximately two years, even though initial plant introductions was purposely sparse and no chemical or organic fertilizers were applied.

Coverage rates varied from seven to $40 \mathrm{~cm}^{2} /$ week (except for Callisia repens with 500) and our best performing species were Kalanchoe fedtschenkoi, Callisia warszewicziana, Callisia fragrans and Tradescantia pallida in decreasing order. Growth rates varying from 5 to $20 \mathrm{~cm}^{2} /$ week were found with 7.5 and $10 \mathrm{~cm}$ substrate thickness using MEG cultivation (Durhman et al., 2007; Bousselot et al., 2010). Adequate plant choice is capable of overcoming the barrier of substrate absence as shown by similar growth rates in relation to MEG.

Plant survival on the greenroof was not dependent upon succulence, which varied from $20 \%$ of the taxa bellow $500 \mathrm{~g} / \mathrm{m}^{2}$ to $9 \%$ above $5,000 \mathrm{~g} / \mathrm{m}^{2}$. Similar findings under a hot Australian climate (Farrell et al., 2012) reinforce this idea: Sedum spurium had the lowest succulence $\left(500 \mathrm{~g} / \mathrm{m}^{2}\right)$ and, despite that, survived longer droughts than native psammophilous species, such as Disphyma crassifolium (Aizoaceae) with $3,100 \mathrm{~g} / \mathrm{m}^{2}$. This median range correlates to about $40 \%$ of the taxa in the present study and it is specifically similar to our results for native lithophytes such as Dyckia brevifolia (Bromeliaceae) with $3,495 \mathrm{~g} / \mathrm{m}^{2}$. Subsequently, Farrell et al. (2013) demonstrated that native lithophytes with much lower succulence than Sedum species, commonly used on greenroofs, can also be drought tolerant and thus good candidates for greenroof use.

Survival and growth on the experimental tropical greenroof has occurred despite diurnal photoinhibition. The majority of quantum yield values were lower than 0.5 when measured during the early afternoon, but were followed by nightly recovery to values above 0.7 during the morning. Such a photochemical recovery was expected, again based upon the choice of plants adapted to extreme tropical solar irradiance on exposed rock outcrops and tree branches (Mattos et al., 1997).

Chlorophyll fluorescence on greenroofs has also been evaluated by numerous authors (Durhman et al., 2006; Getter et al., 2009; Getter and Rowe, 2009; Nektarios et al., 2011; Rowe et al., 2014; Provenzano et al., 2010) because of its potential to reveal and quantify plant stress on such extreme environments. Yield values tipically decreased for plants exposed to more severe drought stress such as those grown under a lower frequency of watering (Durhman et al., 2006) and have also shown a considerable degree of independence from substrate thickness (Getter and Rowe, 2009) but were higher for plants cultivated under overhead irrigation (Rowe et al., 2014) such as the kind employed in our experimental greenroof.

A complex interaction of abiotic factors influences plant survival and growth under the extreme conditions prevailing on tropical greenroofs. To interpret isolated traits such as succulence could provide misleading conclusions. Rather, a set of characters acting together are able to grant resistance to drought, thermal regulation and photochemical inhibition recovery. Proper choice of plants is a key element for the functionality of the new technique. However, it is useless if deprived of a regular water supply in the form of irrigation. Thus, the rich tropical extreme- 
adapted biodiversity is an important ally in order to spread the newly proposed method, being able to furnish an immense array of varied plant material to be tested and adapted to these new artificial ecosystems.

\section{Conclusion}

Substrate free greenroofs are viable under the extreme conditions of tropical humid climates as long as plant choice is based upon shallow rooting epiphytic, lithophytic and psamophyllous species and occasional overhead irrigation is applied. This new system comes from an extreme reduction of the MEG and the consequent minimization of cost for materials and laborand offers many advantages over traditional methodologies, including reduced total weight, easy maintenance and widespread retrofitting possibilities. Future research should focus on lowering of irrigation water used and alternative systems such as dripping as well as fertilizer applications to improve plant growth and survival. Ecological interactions capable of maximizing long-term plant survival as well as associated fauna are also relevant topics to be investigated. Finally, this new technique provides us with the possibility of using tropical epiphytic, lithophytic and psamophyllous species from previously established cultivations, avoiding removal and damage in their natural habitat.

\section{Acknowledgment}

We thank Carolina Reis, Ligia Bicalho, Lawrence Rocha and Juliana Silva for the support during sample collection for succulence and the subsequent lab work, Ligia Bicalho for calculating coverage areas and Carolina Corrêa Abramovicz for improvements to the English version of this manuscript.

\section{Funding}

This study was partially supported by funding from the Coordination for the Improvement of Higher Education Personnel (CAPES) (www.capes.gov.br), Brazil.

\section{Author's Contributions}

Bruno R. Silva: Designed and implemented the new technique purposed, contribute writing the manuscript.

André Mantovani: Collected and analyzed the morpho-physiological data, contribute writing the manuscript and its revision.

Dulce Mantuano: Analyzed the study findings, contribute writing the manuscript and its revision.

Sylvia M. Rolla and Maria C. Barbosa: Contribute writing the manuscript.

\section{Ethics}

This article is original and contains unpublished material. The corresponding author confirms that all of the other authors have read and approved the manuscript and there are no ethical issues involved.

\section{References}

Akbari, H., L.S. Rose and H. Taha, 2003. Analyzing the land cover of an urban environment using highresolution orthophotos. Landscape Urban Plan., 63: 1-14. DOI: 10.1016/S0169-2046(02)00165-2

Ball, M.C., I.R.B. Cowan and D.F. Graham, 1988. Maintenance of leaf temperature and the optimisation of carbon gain in relation to water loss in a tropical mangrove forest. Aust. J. Plant Physiol., 15: 263-276. DOI: 10.1071/PP9880263

Banco Central do Brasil. BCB, Brasilia. http://www.bcb.gov.br

Barker, K.J. and J.D. Lubell, 2012. Effects of species proportions and fertility on Sedum green roof modules. HortTechnology, 22: 196-200. horttech.ashspublications.org/content/22/2/196.full

Beatrice, C.C. and F. Vecchia, 2011. Avaliação do potencial de uso de três espécies vegetais como cobertura leve de telhados em edificações. R C A. Unilasalle, 5: 1-5. DOI: 10.18316/134

Benzing, D.H., 1990. Vascular Epiphytes: General Biology and Related Biota. 1st Edn., Cambridge University Press, UK, ISBN-10: 0521266300, pp: 354

Bousselot, J.M., J.E. Klett and R.D. Koski, 2010. Extensive green roof species evaluations using digital image analysis. HortScience, 45: 1288-1292.

Brenneisen, S., 2006. Space for urban wildlife: Designing green roofs as habitats in Switzerland. Urban Habitats, 4: 27-36.

Carter, T. and L. Fowler, 2008. Establishing greenroof infrastructure through environmental policy instruments. Environ. Manage., 42: 151-164. DOI: $10.1007 / \mathrm{s} 00267-008-9095-5$

Carter, T. and A. Keeler, 2008. Life-cycle cost-benefit analysis of extensive vegetated roof systems. J. Environ. Manage., 87: 350-363. DOI: $10.1016 /$ j.jenvman.2007.01.024

Castleton, H.F., V. Stovin, S.B.M. Beck and J.B. Davison, 2010. Green roofs; building energy savings and the potential for retrofit. Energy Build., 42: 1582-1591. DOI: 10.1016/j.enbuild.2010.05.004

CITES, 2016. CITES Appendix II. https://cites.org/eng/app/index.php

Clark, C., P. Adriaens and F.B. Talbot, 2008. Greenroof valuation: A probabilistic economic analysis of environmental benefits. Environ. Sci. Technol., 42: 2155-2161. DOI: $10.1021 /$ es0706652 
CNC Flora, 2015. http://cncflora.jbrj.gov.br/portal/

Cook-Patton, S.C. and T.L. Bauerle, 2012. Potential benefits of plant diversity on vegetated roofs: A literature review. J. Environ. Manage., 106: 85-92. DOI: 10.1016/j.jenvman.2012.04.003

Dunnett, N.P., 2006. Green roofs for biodiversity: Reconciling aesthetics with ecology. Proceedings of 4th North Fourth Annual International Green Roof Conference: Greening Rooftops for Sustainable Communities, May 11-12, The Cardinal Group, Boston, MA. Toronto, pp: 221-236.

Dunnett, N.P. and A. Nolan, 2004. The effect of substrate depth and supplementary watering on the growth of nine herbaceous perennials in a semiextensive green roof. ActaHort, 643: 305-309. DOI: 10.17660/ActaHortic.2004.643.40

Dunnett, N., A. Nagase, R. Booth and P. Grime, 2008. Influence of vegetation composition on runoff in two simulated green roof experiments. Urban Ecosyst., 11: 385-398. DOI: 10.1007/s1 1252-008-0064-9

Durhman, A.K., D.B. Rowe and C.L. Rugh, 2006. Effect of watering regimen on chlorophyll fluorescence and growth of selected green roof plant taxa. HortScience, 41: 1623-1628.

Durhman, A.K., D.B. Rowe and C.L. Rugh, 2007. Effect of substrate depth on initial growth, coverage and survival of 25 succulent green roof plant taxa. HortScience, 42: 588-595.

Farrell, C., R.E. Mitchell, C. Szota, J.P. Rayner and N.S.G. Williams, 2012. Green roofs for hot and dry climates: Interacting effects of plant water use, succulence and substrate. Ecol. Eng., 49: 270-276. DOI: 10.1016/j.ecoleng.2012.08.036

Farrell, C., C. Szota, N.S.G. Williams and S.K. Arndt, 2013. High water users can be drought tolerant: Using physiological traits for greenroof plant selection. Plant Soil, 372: 177-193. DOI: $10.1007 / \mathrm{s} 11104-013-1725-\mathrm{x}$

Fioretti, R., A. Palla, L.G. Lanza and P. Principi, 2010. Green roof energy and water related performance in the Mediterranean climate. Build Environ., 45: 1890-1904. DOI: 10.1016/j.buildenv.2010.03.001

Franco, A.C. and P.S. Nobel, 1989. Effect of nurse plants on the microhabitat and growth of cacti. J. Ecol., 77: 870-886. DOI: 10.2307/2260991

Frazer, L., 2005. Paving Paradise: The peril of impervious surfaces. Environ. Health Perspect., 113: A456-A462. DOI: 10.1289/ehp.113-a456

Genty, B., J.M. Briantai and N.R. Baker, 1989. The relationship between quantum yield of photosynthetic electron transport and quenching of chlorophyll fluorescence. Biochim. Biophys. Acta, 990: 87-92. DOI: 10.1016/S0304-4165(89)80016-9

Getter, K.L. and D.B. Rowe, 2006. The role of extensive green roofs in sustainable development. HortScience, 41: 1276-1285.
Getter, K.L. and D.B. Rowe, 2008. Media depth influences Sedum green roof establishment. Urban Ecosyst., 11: 361-372. DOI: $10.1007 / \mathrm{s} 11252-008-0052-0$

Getter, K.L. and D.B. Rowe, 2009. Substrate depth influences sedum plant community on a green roof. HortScience, 44: 401-407.

Getter, K.L., D.B. Rowe and M.C. Bert, 2009. Solar radiation intensity influences extensive greenroof plant communities. Urban Urban Gree., 8: 269-281. DOI: $10.1016 /$ j.ufug.2009.06.005

Henry, A. and N. Frascaria-Lacoste, 2012. The greenroof dilemma: Discussion of Francis and Lorimer (2011). J. Environ. Manage., 104: 91-92. DOI: $10.1016 /$ j.jenvman.2012.03.040

IUCN Red List, 2017. The international union for conservation of nature. IUCN Global Species Programme Red List Unit, Cambridge. http://www.iucnredlist.org/

Kluge, M. and I.P. Ting, 1978. Crassulacean Acid Metabolism. 1st Edn., Springer-Verlag, New York, ISBN-10: 0387089799, pp: 209.

Köhler, M., 2006. Long-term vegetation research on two extensive green roofs in Berlin. Urban Habitats, 4: 3-26.

Köhler, M. and P.H. Poll, 2010. Long-term performance of selected old Berlin greenroofs in comparison to younger extensive greenroofs in Berlin. Ecol. Eng., 36: 722-729. DOI: 10.1016/j.ecoleng.2009.12.019

Laar, M. and F.W. Grimme, 2006. Thermal comfort and reduced flood risk through green roofs in the tropics. Proceedings of the 23rd Conference on Passive and Low Energy Architecture, Sept. 6-8, Geneva, Switzerland.

Laar, M., C.G. Souza, V.L.A. Paiva, N.A. Amigo and S. Tavares et al. 2001. Estudo de aplicação de plantas em telhados vivos extensivos em cidades de clima tropical. Anais do VI Encontro Nacional e III Encontro Latino-Americano de Conforto no Ambiente Construído, Nov. 11-14, CD-ROM, São Pedro, São Paulo.

Leigh, A., S. Sevanto, M.C. Ball, J.D. Close and D.S. Ellsworth, 2012. Do thick leaves avoid thermal damage in critically low wind speeds? New Phytol., 194: 477-487. DOI: $10.1111 /$ j.1469-8137.2012.04058.x

Logendra, L.S. and H.W. Janes, 1997. Hydroponics tomato production: Growing media requirements. Acta Hort., 481: 483-486. DOI: 10.17660/ActaHortic. 1999.481.56

Lundholm, J., J.S. MacIvor, Z. MacDougall and M. Ranalli, 2010. Plant species and functional group combinations affect greenroof ecosystem functions. Plos One, 5: e9677-e9677. DOI: 10.1371/journal.pone 
Lüttge, U., 2004. Ecophysiology of Crassulacean Acid Metabolism (CAM). Ann Bot., 93: 629-652. DOI: $10.1093 / \mathrm{aob} / \mathrm{mch} 087$

Madre, F., A. Vergnes, N. Machon and P. Clergeau, 2014. Green roofs as habitats for wild plant species in urban landscapes: first insights from a large-scale sampling. Landscape Urban Plan., 122: 100-107. DOI: 10.1016/j.landurbplan.2013.11.012

Magill, J.D., K. Midden, J. Groninger and M. Therrell, 2011. A history and definition of green roof technology with recommendations for future research. Research Papers. http://opensiuc.lib.siu.edu/gs_rp/91

Mantovani, A. and R.R. Iglesias, 2001. Bromélias terrestres na restinga de Barra de Maricá, Rio de Janeiro: Influência sobre o microclima, o solo e a estocagem de nutrientes em ambientes de borda de moitas. Leandra, 16: 17-37.

Mantovani, A. and R.R. Iglesias, 2005. Quando aparece a primeira escama? Estudo comparativo sobre $o$ surgimento de escamas de absorção em três espécies de bromélias terrestres de restinga. Rodriguésia, 56: 73-84. DOI: 10.1590/2175-78602005568705

Mantovani, A. and R.R. Iglesias, 2010. The effect of water stress on seed germination of three terrestrial bromeliads from restinga. Braz. J. Bot., 33: 201-205. DOI: $10.1590 / \mathrm{S} 0100-84042010000100017$

Mantovani, A., 1999. Leaf morpho-physiology and distribution of epiphytic aroids along a vertical gradient in a Brazilian rain forest. Selbyana, 20: 241-249.

Mantuano, D.G., C.F. Barros and F.R. Scarano, 2006. Leaf anatomy variation within and between three "resting" populations of Erythroxylum ovalifolium Peyr. (Erythroxylaceae) in Southeast Brazil. Rev. Bras. Bot., 29: 209-215.

DOI: $10.1590 / \mathrm{S} 0100-84042006000200002$

Martinelli, G. and M.A. Moraes, 2013. Livro vermelho da flora do Brasil., Centro Nacional de Conservação da Flora, Rio de Janeiro Andrea Jakobsson.

Mattos, E.A., T.E. Grams, E. Ball, A.C. Franco and A. Haagkerwer et al., 1997. Diurnal patterns of chlorophyll a fluorescence and stomatal conductance in several species of coastal vegetation in southeastern Brazil. Trees, 11: 363-369. DOI: 10.1007/PL00009680

Maxwell, K. and G.N. Johnson, 2000. Chlorophyll fluorescence - a practical guide. J. Exp. Bot., 51: 659-668. DOI: $10.1093 /$ jexbot/51.345.659

McGuire, K.L., S.G. Payne, M.I. Palmer, C.M. Gillikin and D. Keefe et al., 2013. Digging the New York City Skyline: Soil fungal communities in Green Roofs and City Parks. PloS One, 8: e58020-e58020. DOI: 10.1371/journal.pone.0058020

Mittermeier, R.A., W.R. Turner, F.W. Larsen, T.M. Brooks and C. Gascon, 2011. Global Biodiversity Conservation: The Critical Role of Hotspots. In: Biodiversity Hotspots, Zachos, F.E. and J.C. Habel (Eds.), Springer Publishers, London, pp: 3-22.
Nagase, A. and N. Dunnett, 2010. Drought tolerance in different vegetation types for extensive green roofs: Effects of watering and diversity. Landscape Urban Plan., 97: 318-327.

Nektarios, P.A., I. Amountzias, I. Kokkinou and N. Ntoulas, 2011. Greenroof substrate type and depth affect the growth of the native species Dianthus fruticosus under reduced irrigation regimens. Hort. Sci., 46: 1208-1216.

Nieder, J., J. Prosperí and G. Michaloud, 2001. Epiphytes and their contribution to canopy diversity. Plant Ecol., 153: 51-63.

DOI: $10.1023 / \mathrm{A}: 1017517119305$

Niklas, K.J., 1994. Plant Allometry: The Scaling of form and Process. University of Chicago Press, Cambridge, ISBN-10: 226-58081-4.

Oberndorfer, E., J. Lundholm, B. Brass, R. Coffmann and H. Doshi et al., 2007. Green roofs as urban ecosystems: Ecological structures, functions and services. Bioscience, 57: 823-833.

DOI: 10.1641/B571005

Osmundson, T., 1999. Roof Gardens: History, Design and Construction. WW Norton and Company, New York.

Parizotto, S. and R. Lamberts, 2011. Investigation of greenroof thermal performance in temperate climate: A case study of an experimental building in Florianópolis city, Southern Brazil. Energ. Build., 43: 1712-1722. DOI: 10.1016/j.enbuild.2011.03.014

Porembski, S. and W. Barthlott, 2000. Granitic and gneissic outcrops (inselbergs) as centers of diversity for desiccation-tolerant vascular plants. Plant Ecol., 151: 19-28. DOI: 10.1023/A:1026565817218

Provenzano, M.E., M. Cardarelli, F. Saccardo, G. Colla and A. Battistelli et al., 2010. Evaluation of perennial herbaceous species for their potential use in a green roof under mediterranean climate conditions. Acta Hortic., 881: 661-667. DOI: 10.17660/ActaHortic.2010.881.109

Rosseti, K., L. Durante, I. Callejas, M. Nogueira and J. Nogueira, 2013. Abordagem sobre as barreiras e benefícios da utilização do sistema de telhado verde em áreas urbanas de regiões tropicais. Brazil. Geograph. J.: Geosci. Humanities Res. Medium, 4: 55-77.

Rowe, D.B., M.R. Kolp, S.E. Greer and K.L. Getter, 2014. Comparison of irrigation efficiency and plant health of overhead, drip and sub-irrigation for extensive green roofs. Ecol. Eng., 64: 306-313. DOI: $10.1016 /$ j.ecoleng.2013.12.052

Tropicos database, 2016. http://tropicos.org/

Sendo, T., M. Kanechi, Y. Uno and N. Inagaki, 2010. Evaluation of growth and green coverage of ten ornamental species for planting as urban rooftop greening. J. Jpn. Soc. Hortic. Sci., 79: 69-76. DOI: $10.2503 /$ jjshs 1.79 .69 
Silva, B.R., 2016. Telhados verdes em clima tropical: Uma nova técnica e seu potencial de atenuação térmica. $\mathrm{PhD}$ Thesis, Coppe - Instituto Alberto Luiz Coimbra de Pós-Graduação e Pesquisa de Engenharia, Universidade Federal do Rio de Janeiro, Brazil.

Simmons, M.T., B. Gardiner, S. Windhager and J. Tinsley, 2008. Green roofs are not created equal: the hydrologic and thermal performance of six different extensive green roofs and reflective and nonreflective roofs in a sub-tropical climate. Urban Ecosyst., 11: 339-348.

DOI: $10.1007 / \mathrm{s} 11252-008-0069-4$

Susca, T., S.R. Gaffin, G.R. Dell'osso, 2011. Positive effects of vegetation: Urban heat island and green roofs. Environ. Pollut., 159: 2119-2126.

DOI: 10.1016/j.envpol.2011.03.007

Tan, P.Y. and A. Sia, 2009. Understanding the performance of plants on non-irrigated green roofs in Singapore using a biomass yield approach. Nat. Singapore, 2: 149-153.

Thuring, C.E. and N. Dunnett, 2014. Vegetation composition of old extensive green roofs (from 1980s Germany). Ecol. Process, 3: 1-11.

DOI: $10.1186 / 2192-1709-3-4$
Vecchia, F., 2005. Cobertura Verde Leve (CVL): Ensaio experimental. In: Anais do VIII Encontro Nacional de Conforto no Ambiente Construído (ENCAC) e IV Encontro Latino-Americano de Conforto no Ambiente Construído, Oct. 5-7, Maceió.Alagoas.

Warton, D.I., I.J. Wright, D.S. Falster and M. Westoby, 2006. Bivariate line-fitting methods for allometry. Biol. Rev., 81: 259-291.

DOI: $10.1017 / \mathrm{S} 1464793106007007$

Wolf, D. and J.T. Lundholm, 2008. Water uptake in green roof microcosms: effects of plant species and water availability. Ecol. Eng., 33: 179-186. DOI: 10.1016/j.ecoleng.2008.02.008

Wong, N.H., S.F. Tay, R. Wong, C.L. Ong and A. Sia, 2003. Life cycle cost analysis of rooftop gardens in Singapore. Build. Environ., 38: 499-509. DOI: 10.1016/S0360-1323(02)00131-2

Zar, J.H., 1996. Biostatistical Analysis. Prentice Hall, New Jersey, ISBN-10: 0130845426.

Zotz, G. and V. Thomas, 1999. How much water is in the tank? Model calculations for two epiphytic bromeliads. Ann. Bot., 83: 183-192. DOI: 10.1006/anbo.1998.0809

\section{Appendix 1}

List of species grown under the three-layer technique proposed for a tropical greenroof. Scientific names updated according to the online taxonomic database Tropicos (2016) (http://tropicos.org/). Conservation status obtained from IUCN Red List (2017) (http://www.iucnredlist.org/); Martinelli and Moraes (2013); CNCFlora (2015) (http://cncflora.jbrj.gov.br/portal/) or CITES CITES (2016) Appendix II

\begin{tabular}{|c|c|c|c|c|c|}
\hline Family & Species & Origin & Growth form & Habit & Conservation \\
\hline Acanthaceae & $\begin{array}{l}\text { Ruellia simplex Wright } \\
\text { endemic }\end{array}$ & $\begin{array}{l}\text { Native not } \\
\text { Herb }\end{array}$ & Terrestrial & Not listed & \\
\hline Amaryllidaceae & Allium fistulosum $\mathrm{L}$. & Exotic & Herb & Terrestrial & Not listed \\
\hline Amaryllidaceae & Allium tuberosum Rottler ex Spreng. & Exotic & Herb & Terrestrial & Not listed \\
\hline Apocynaceae & $\begin{array}{l}\text { Adenium obesum (Forssk.) Roem. } \\
\text { and Schult. }\end{array}$ & Exotic & $\begin{array}{l}\text { Arbusto } \\
\text { suculento }\end{array}$ & Lithophyte & Not listed \\
\hline Apocynaceae & $\begin{array}{l}\text { Huernia macrocarpa Schweinfurth } \\
\text { ex K. Schum. }\end{array}$ & Exotic & Succulent & Lithophyte & Not listed \\
\hline Apocynaceae & $\begin{array}{l}\text { Orbea caudata subsp. Rhodesiaca } \\
\text { (L.C. Leach) Bruyns }\end{array}$ & Exotic & Succulent & Lithophyte & Not listed \\
\hline Apocynaceae & $\begin{array}{l}\text { Pachypodium geayi Costantin } \\
\text { and Bois }\end{array}$ & Exotic & Árvore succulent & Lithophyte & $\begin{array}{l}\text { CITES } \\
\text { Appendix II }\end{array}$ \\
\hline Apocynaceae & Pachypodium lamerei Drake & Exotic & Árvore succulent & Lithophyte & CITES Appendix II \\
\hline Apocynaceae & Pachypodium saundersii N.E. Br. & Exotic & Arbusto suculento & Lithophyte & Not listed \\
\hline Apocynaceae & Plumeria rubra $\mathrm{L}$. & Exotic & Tree - small & Terrestrial & Not listed \\
\hline Apocynaceae & Stapelia hirsuta L. & Exotic & Succulent & Lithophyte & Not listed \\
\hline Araceae & $\begin{array}{l}\text { Alocasia 'Amazonica'(Alocasia } \\
\text { sanderiana x Alocasia lowii) }\end{array}$ & Híbrido artificial & Herb & Terrestrial & Not applicable \\
\hline Araceae & $\begin{array}{l}\text { Colocasia esculenta var. } \\
\text { aquatilis Hassk. }\end{array}$ & Exotic & Aquática & Aquatic & $\begin{array}{l}\text { Least Concern } \\
(\mathrm{IUCN})\end{array}$ \\
\hline Araceae & $\begin{array}{l}\text { Philodendron crassinervium } \\
\text { Lindl. }\end{array}$ & Native endemic & Liana & $\begin{array}{l}\text { Epithyte/ } \\
\text { Lithophyte/ } \\
\text { HemiEpithyte }\end{array}$ & Not listed \\
\hline Araceae & $\begin{array}{l}\text { Philodendron warszewiczii K. } \\
\text { Koch and C.D. Bouché }\end{array}$ & Exotic & Liana & $\begin{array}{l}\text { Epithyte/ } \\
\text { Lithophyte }\end{array}$ & Not listed \\
\hline Arecaceae & $\begin{array}{l}\text { Bismarckia nobilis Hildebrandt } \\
\text { and H. Wendl. }\end{array}$ & Exotic & Tree - small & Terrestrial & Least Concern (IUCN) \\
\hline Arecaceae & Chamaedorea seifrizii Burret & Exotic & Shrub - large & Terrestrial & Not listed \\
\hline Asparagaceae & Agave americana var.marginata & Exotic & Shrub - large & Lithophyte/ & Not listed \\
\hline
\end{tabular}




\begin{tabular}{|c|c|c|c|c|c|}
\hline Asparagaceae & $\begin{array}{l}\text { Trel. } \\
\text { Agave attenuata Salm-Dyck }\end{array}$ & Exotic & Shrub - large & $\begin{array}{l}\text { Lithophyte/ } \\
\text { Terrestrial }\end{array}$ & $\begin{array}{l}\text { Terrestrial } \\
\text { Not listed }\end{array}$ \\
\hline Asparagaceae & Agave franzosinii P.Sewell & Exotic & Shrub - large & $\begin{array}{l}\text { Lithophyte/ } \\
\text { Terrestrial }\end{array}$ & Not listed \\
\hline Asparagaceae & Agave gypsophila Gentry & Exotic & Shrub - small & Lithophyte & Not listed \\
\hline Asparagaceae & $\begin{array}{l}\text { Agave vilmoriniana (leaves } \\
\text { erect) A. Berger }\end{array}$ & Exotic & Shrub - large & Lithophyte & Not listed \\
\hline Asparagaceae & $\begin{array}{l}\text { Agave vilmoriniana (spiraled } \\
\text { leaves)A. Berger }\end{array}$ & Exotic & Shrub - large & Lithophyte & Not listed \\
\hline Asparagaceae & Agave weberi F. Cels ex J. Poiss. & Exotic & Shrub - large & $\begin{array}{l}\text { Lithophyte/ } \\
\text { Terrestrial }\end{array}$ & Not listed \\
\hline Asparagaceae & Beaucarnea recurvata Lem. & Exotic & Shrub - large & $\begin{array}{l}\text { Lithophyte/ } \\
\text { Terrestrial }\end{array}$ & Not listed \\
\hline Asparagaceae & Dracaena draco (L.) L. & Exotic & Tree - small & $\begin{array}{l}\text { Lithophyte/ } \\
\text { Terrestrial }\end{array}$ & $\begin{array}{l}\text { Vulnerable } \\
\text { (IUCN) }\end{array}$ \\
\hline Asparagaceae & $\begin{array}{l}\text { Dracaena reflexa var. } \\
\text { angustifólia Baker }\end{array}$ & Exotic & Tree - small & $\begin{array}{l}\text { Lithophyte/ } \\
\text { Terrestrial }\end{array}$ & Not listed \\
\hline Asparagaceae & Sansevieria 'Alva' & Híbrido artificial & Succulent & $\begin{array}{l}\text { Lithophyte/ } \\
\text { Terrestrial }\end{array}$ & Not applicable \\
\hline Asparagaceae & $\begin{array}{l}\text { Sansevieria ehrenbergii } \\
\text { Schweinf. ex Baker }\end{array}$ & Exotic & Succulent & $\begin{array}{l}\text { Lithophyte/ } \\
\text { Terrestrial }\end{array}$ & Not listed \\
\hline Asparagaceae & Sansevieria 'Fernwood' & Artificial cultivar & Succulent & $\begin{array}{l}\text { Lithophyte/ } \\
\text { Terrestrial }\end{array}$ & Not applicable \\
\hline Asparagaceae & $\begin{array}{l}\text { Sansevieria masoniana } \\
\text { Chahinian }\end{array}$ & Exotic & Succulent & $\begin{array}{l}\text { Lithophyte/ } \\
\text { Terrestrial }\end{array}$ & Not listed \\
\hline Asparagaceae & Sansevieria parva N.E. Br. & Exotic & Succulent & $\begin{array}{l}\text { Lithophyte/ } \\
\text { Terrestrial }\end{array}$ & Not listed \\
\hline Asparagaceae & $\begin{array}{l}\text { Sansevieria trifasciata } \\
\text { 'Bantel's Sensation' }\end{array}$ & Artificial cultivar & Succulent & $\begin{array}{l}\text { Lithophyte/ } \\
\text { Terrestrial }\end{array}$ & Not applicable \\
\hline Asparagaceae & $\begin{array}{l}\text { Sansevieria trifasciata 'Black } \\
\text { Coral' }\end{array}$ & Artificial cultivar & Succulent & $\begin{array}{l}\text { Lithophyte/ } \\
\text { Terrestrial }\end{array}$ & Not applicable \\
\hline Asparagaceae & $\begin{array}{l}\text { Sansevieria trifasciata } \\
\text { 'Moonshine' }\end{array}$ & Artificial cultivar & Succulent & $\begin{array}{l}\text { Lithophyte/ } \\
\text { Terrestrial }\end{array}$ & Not applicable \\
\hline Asparagaceae & $\begin{array}{l}\text { Sansevieria trifasciata var } \\
\text { laurentii (De Wild.) N.E. Br. }\end{array}$ & Exotic & Succulent & $\begin{array}{l}\text { Lithophyte/ } \\
\text { Terrestrial }\end{array}$ & Not listed \\
\hline Asteraceae & Senecio crassissimus Humbert & Exotic & Succulent & $\begin{array}{l}\text { Lithophyte/ } \\
\text { Terrestrial }\end{array}$ & Not listed \\
\hline Asteraceae & Senecio serpens G.D. Rowley & Exotic & Succulent & $\begin{array}{l}\text { Lithophyte/ } \\
\text { Terrestrial }\end{array}$ & Not listed \\
\hline $\begin{array}{l}\text { Asteraceae } \\
\text { Bromeliaceae }\end{array}$ & $\begin{array}{l}\text { Senecio sp. } \\
\text { Acanthostachys strobilacea (Schult. }\end{array}$ & Native not & Succulent & Epithyte & Not listed \\
\hline Bromeliaceae & $\begin{array}{l}\text { Aechmea amicorum B. R. Silva } \\
\text { and H. Luther }\end{array}$ & Native endemic & Herb & Psammophilous & $\begin{array}{l}\text { Endangered } \\
\text { (Martinelli and } \\
\text { Moraes, 2013) }\end{array}$ \\
\hline Bromeliaceae & $\begin{array}{l}\text { Aechmea bambusoides L.B. Sm. } \\
\text { and Reitz }\end{array}$ & Native endemic & Herb & Epithyte & $\begin{array}{l}\text { Vulnerable } \\
\text { (Martinelli and } \\
\text { Moraes, 2013) }\end{array}$ \\
\hline Bromeliaceae & $\begin{array}{l}\text { Aechmea blanchetiana (Baker) } \\
\text { L.B. Sm. }\end{array}$ & Native endemic & Herb & Psammophilous & Not listed \\
\hline Bromeliaceae & $\begin{array}{l}\text { Aechmea cephaloides J.A.Siqueira } \\
\text { and Leme }\end{array}$ & Native endemic & Herb & $\begin{array}{l}\text { Epithyte/ } \\
\text { Terrestrial }\end{array}$ & Not listed \\
\hline Bromeliaceae & Aechmea chantinii (Carrière) Baker & $\begin{array}{l}\text { Native not } \\
\text { endemic }\end{array}$ & Herb & Epithyte & Not listed \\
\hline Bromeliaceae & Aechmea comata (Gaudich.) Baker & Native endemic & Herb & $\begin{array}{l}\text { Epithyte/ } \\
\text { Lithophyte }\end{array}$ & Not listed \\
\hline Bromeliaceae & $\begin{array}{l}\text { Aechmea correia-araujoi E. } \\
\text { Pereira and Moutinho }\end{array}$ & Native endemic & Herb & Epithyte & Not listed \\
\hline Bromeliaceae & Aechmea depressa L.B. Sm. & Native endemic & Herb & $\begin{array}{l}\text { Epithyte/ } \\
\text { Terrestrial }\end{array}$ & $\begin{array}{l}\text { Endangered } \\
\text { (Martinelli and } \\
\text { Moraes, 2013) }\end{array}$ \\
\hline Bromeliaceae & Aechmea distichantha Lem. & Native endemic & Herb & $\begin{array}{l}\text { Lithophyte/ } \\
\text { Epithyte/ } \\
\text { Terrestrial }\end{array}$ & Not listed \\
\hline
\end{tabular}




\begin{tabular}{|c|c|c|c|c|c|}
\hline Bromeliaceae & $\begin{array}{l}\text { Aechmea floribunda Mart. } \\
\text { ex Schult. and Schult. f. }\end{array}$ & Native endemic & Herb & $\begin{array}{l}\text { Epithyte/ } \\
\text { Terrestrial/ } \\
\text { Psammophilous }\end{array}$ & Not listed \\
\hline Bromeliaceae & $\begin{array}{l}\text { Aechmea leptantha (Harms) } \\
\text { Leme and J.A. Siqueira }\end{array}$ & Native endemic & Herb & $\begin{array}{l}\text { Epithyte/ } \\
\text { Lithophyte/ } \\
\text { Terrestrial }\end{array}$ & Not listed \\
\hline Bromeliaceae & $\begin{array}{l}\text { Aechmea nudicaulis (cv. 1)(L.) } \\
\text { Griseb. }\end{array}$ & $\begin{array}{l}\text { Native not } \\
\text { endemic }\end{array}$ & Herb & $\begin{array}{l}\text { Epithyte/ } \\
\text { Lithophyte }\end{array}$ & Not listed \\
\hline Bromeliaceae & $\begin{array}{l}\text { Aechmea nudicaulis (cv. 2)(L.) } \\
\text { Griseb. }\end{array}$ & $\begin{array}{l}\text { Native not } \\
\text { endemic }\end{array}$ & Herb & $\begin{array}{l}\text { Epithyte/ } \\
\text { Lithophyte }\end{array}$ & Not listed \\
\hline Bromeliaceae & Aechmea orlandiana L.B. Sm. & Native endemic & Herb & Epithyte & $\begin{array}{l}\text { Critically } \\
\text { endangered } \\
\text { (Martinelli and } \\
\text { Moraes, 2013) }\end{array}$ \\
\hline Bromeliaceae & Aechmea pectinata Baker & Native endemic & Herb & $\begin{array}{l}\text { Epithyte/ } \\
\text { Terrestrial }\end{array}$ & Not listed \\
\hline Bromeliaceae & $\begin{array}{l}\text { Aechmea pineliana (Brongn. } \\
\text { ex Planch.) Baker }\end{array}$ & Native endemic & Herb & $\begin{array}{l}\text { Epithyte/ } \\
\text { Lithophyte/ } \\
\text { Psammophilous }\end{array}$ & Not listed \\
\hline Bromeliaceae & Aechmea 'Purple Gem' & Híbrido artificial & Herb & Epithyte & Not applicable \\
\hline Bromeliaceae & Aechmea tocantina Baker & $\begin{array}{l}\text { Native not } \\
\text { endemic }\end{array}$ & Herb & $\begin{array}{l}\text { Epithyte/ } \\
\text { Lithophyte }\end{array}$ & Not listed \\
\hline Bromeliaceae & $\begin{array}{l}\text { Alcantarea glaziouana (Leme) } \\
\text { J.R.Grant }\end{array}$ & Native endemic & Herb & Lithophyte & $\begin{array}{l}\text { Endangered } \\
\text { (Martinelli and } \\
\text { Moraes, 2013) }\end{array}$ \\
\hline Bromeliaceae & $\begin{array}{l}\text { Alcantarea nahoumii (Leme) } \\
\text { J.R.Grant }\end{array}$ & Native endemic & Herb & Lithophyte & $\begin{array}{l}\text { Vulnerable } \\
\text { (Martinelli and } \\
\text { Moraes, 2013) }\end{array}$ \\
\hline Bromeliaceae & $\begin{array}{l}\text { Alcantarea odorata (Leme) } \\
\text { J.R.Grant }\end{array}$ & Native endemic & Herb & Lithophyte & Not listed \\
\hline Bromeliaceae & $\begin{array}{l}\text { Alcantarea vinicolor (E.Pereira } \\
\text { and Reitz) J.R.Grant }\end{array}$ & Native endemic & Herb & Lithophyte & $\begin{array}{l}\text { Endangered } \\
\text { (Martinelli and } \\
\text { Moraes, 2013) }\end{array}$ \\
\hline Bromeliaceae & Ananas (Nahoum) & Artificial cultivar & Herb & $\begin{array}{l}\text { Lithophyte/ } \\
\text { Terrestrial }\end{array}$ & Not applicable \\
\hline Bromeliaceae & Ananas comosus (L.) Merr. & Artificial cultivar & Herb & $\begin{array}{l}\text { Lithophyte/ } \\
\text { Terrestrial }\end{array}$ & Not applicable \\
\hline Bromeliaceae & $\begin{array}{l}\text { Billbergia amoena var. rubra } \\
\text { M.B. Foster }\end{array}$ & Native endemic & Herb & Epithyte & Not listed \\
\hline Bromeliaceae & Billbergia 'Hallelujah' & Artificial cultivar & Herb & Epithyte & Not applicable \\
\hline Bromeliaceae & Billbergia sp. 1 & & Herb & Epithyte & \\
\hline Bromeliaceae & Brocchinia micrantha (Baker) Mez & Exotic & Herb & $\begin{array}{l}\text { Lithophyte/ } \\
\text { Terrestrial }\end{array}$ & Not listed \\
\hline Bromeliaceae & $\begin{array}{l}\text { Canistrum alagoanum Leme and } \\
\text { J.A.Siqueira }\end{array}$ & Native endemic & Herb & $\begin{array}{l}\text { Epithyte/ } \\
\text { Lithophyte }\end{array}$ & $\begin{array}{l}\text { Endangered } \\
\text { (Martinelli and } \\
\text { Moraes, 2013) }\end{array}$ \\
\hline Bromeliaceae & Canistrum aurantiacum $\mathrm{E}$. Morren & Native endemic & Herb & $\begin{array}{l}\text { Epithyte/ } \\
\text { Terrestrial }\end{array}$ & $\begin{array}{l}\text { Endangered } \\
\text { (Martinelli and } \\
\text { Moraes, 2013) }\end{array}$ \\
\hline Bromeliaceae & Cryptanthus schwackeanus $\mathrm{Mez}$ & Native endemic & Herb & Lithophyte & Not listed \\
\hline Bromeliaceae & $\begin{array}{l}\text { Deuterocohnia meziana Kuntze } \\
\text { ex Mez }\end{array}$ & Native not & Herb & $\begin{array}{l}\text { Lithophyte } \\
\text { endemic }\end{array}$ & $\begin{array}{l}\text { Vulnerable } \\
\text { (Martinelli and } \\
\text { Moraes, 2013) }\end{array}$ \\
\hline Bromeliaceae & Dyckia brevifolia Baker & Native endemic & Succulent & Lithophyte & Not listed \\
\hline Bromeliaceae & Dyckia choristaminea $\mathrm{Mez}$ & Native endemic & Succulent & Lithophyte & Not listed \\
\hline Bromeliaceae & Encholirium horridum L.B. Sm. & Native endemic & Succulent & Lithophyte & $\begin{array}{l}\text { Endangered: EN } \\
\text { B2ab(iii) } \\
\text { (Martinelli and } \\
\text { Moraes, 2013) }\end{array}$ \\
\hline Bromeliaceae & Fosterella sp. & & Herb & Lithophyte & \\
\hline Bromeliaceae & Hechtia rosea E. Morren ex Baker & Exotic & Succulent & Lithophyte & Not listed \\
\hline Bromeliaceae & $\begin{array}{l}\text { Hohenbergia castellanosii L.B. } \\
\text { Sm. and Read }\end{array}$ & Native endemic & Herb & Psammophilous & $\begin{array}{l}\text { Endangered } \\
\text { (Martinelli and } \\
\text { Moraes, 2013) }\end{array}$ \\
\hline Bromeliaceae & Hohenbergia correia-araujoi $\mathrm{E}$. & Native endemic & Herb & Epithyte & Critically endangered \\
\hline
\end{tabular}




\begin{tabular}{|c|c|c|c|c|c|}
\hline & Pereira and Moutinho & & & & $\begin{array}{l}\text { (Martinelli and } \\
\text { Moraes, 2013) }\end{array}$ \\
\hline Bromeliaceae & Hohenbergia pennae E. Pereira & Native endemic & Herb & Lithophyte & Not listed \\
\hline Bromeliaceae & Hohenbergia sp. 1 & Native endemic & Herb & Lithophyte & \\
\hline Bromeliaceae & Hohenbergia sp. 2 & Native endemic & Herb & Lithophyte & \\
\hline Bromeliaceae & Hohenbergia sp. 3 & Native endemic & Herb & Lithophyte & \\
\hline Bromeliaceae & Hohenbergia sp. 4 & Native endemic & Herb & Lithophyte & \\
\hline Bromeliaceae & $\begin{array}{l}\text { Neoregelia camorimiana E. } \\
\text { Pereira and I.A. Penna }\end{array}$ & Native endemic & Herb & Epithyte & Not listed \\
\hline Bromeliaceae & $\begin{array}{l}\text { Neoregelia carcharodon (Baker) } \\
\text { L.B. Sm. }\end{array}$ & Native endemic & Herb & $\begin{array}{l}\text { Epithyte/ } \\
\text { Terrestrial }\end{array}$ & Not listed \\
\hline Bromeliaceae & $\begin{array}{l}\text { Neoregelia compacta }(\mathrm{Mez}) \\
\text { L.B. Sm. }\end{array}$ & Native endemic & Herb & $\begin{array}{l}\text { Epithyte/ } \\
\text { Lithophyte }\end{array}$ & Not listed \\
\hline Bromeliaceae & $\begin{array}{l}\text { Neoregelia concentrica (Vell.) } \\
\text { L.B. Sm. }\end{array}$ & Native endemic & Herb & $\begin{array}{l}\text { Epithyte/ } \\
\text { Terrestrial }\end{array}$ & Not listed \\
\hline Bromeliaceae & $\begin{array}{l}\text { Neoregelia cruenta (R.Graham) } \\
\text { L.B.Sm. }\end{array}$ & Native endemic & Herb & $\begin{array}{l}\text { Psammophilous/ } \\
\text { Lithophyte }\end{array}$ & Not listed \\
\hline Bromeliaceae & Neoregelia cv. 1 & Artificial cultivar & Herb & $\begin{array}{l}\text { Epithyte/ } \\
\text { Lithophyte }\end{array}$ & Not applicable \\
\hline Bromeliaceae & Neoregelia 'Fireball' & Artificial cultivar & Herb & $\begin{array}{l}\text { Epithyte/ } \\
\text { Lithophyte }\end{array}$ & Not applicable \\
\hline Bromeliaceae & Neoregelia leviana L.B. Sm. & $\begin{array}{l}\text { Native not } \\
\text { endemic }\end{array}$ & Herb & Epithyte & Not listed \\
\hline Bromeliaceae & Neoregelia pendula L.B. Sm. & Exotic & Herb & Epithyte & Not listed \\
\hline Bromeliaceae & Neoregelia 'Sarada' & Artificial cultivar & Herb & $\begin{array}{l}\text { Epithyte/ } \\
\text { Lithophyte }\end{array}$ & Not applicable \\
\hline Bromeliaceae & Orthophytum sp. 1 & & Herb & Lithophyte & \\
\hline Bromeliaceae & Orthophytum vagans M.B. Foster & Native endemic & Herb & Lithophyte & Not listed \\
\hline Bromeliaceae & Pitcairnia encholirioides L.B. Sm. & Native endemic & Herb & Lithophyte & $\begin{array}{l}\text { Endangered } \\
\text { (Martinelli and } \\
\text { Moraes, 2013) }\end{array}$ \\
\hline Bromeliaceae & Pitcairnia 'Rhubarb' & Artificial cultivar & Herb & Lithophyte & Not applicable \\
\hline Bromeliaceae & Pitcairnia sp. 1 & & Herb & Lithophyte & \\
\hline Bromeliaceae & Pitcairnia staminea Lodd. & Native endemic & Herb & Lithophyte & Not listed \\
\hline Bromeliaceae & Portea alatisepala Philcox & Native endemic & Herb & $\begin{array}{l}\text { Epithyte/ } \\
\text { Terrestrial }\end{array}$ & $\begin{array}{l}\text { Vulnerable } \\
\text { (Martinelli and } \\
\text { Moraes, 2013) }\end{array}$ \\
\hline Bromeliaceae & $\begin{array}{l}\text { Quesnelia edmundoi var. } \\
\text { intermedia E. Pereira and Leme }\end{array}$ & Native endemic & Herb & Epithyte & Not listed \\
\hline Bromeliaceae & $\begin{array}{l}\text { Quesnelia marmorata (Lem.) } \\
\text { R.W.Read }\end{array}$ & Native endemic & Herb & Epithyte & Not listed \\
\hline Bromeliaceae & $\begin{array}{l}\text { Tillandsia andreana E. Morren } \\
\text { ex André }\end{array}$ & Exotic & Herb & Epithyte & Not listed \\
\hline Bromeliaceae & Tillandsia araujei $\mathrm{Mez}$ & Native endemic & Herb & Lithophyte & $\begin{array}{l}\text { Endangered } \\
\text { (Martinelli and } \\
\text { Moraes, 2013) }\end{array}$ \\
\hline Bromeliaceae & Tillandsia bulbosa Hook. & $\begin{array}{l}\text { Native not } \\
\text { endemic }\end{array}$ & Herb & Epithyte & Not listed \\
\hline Bromeliaceae & Tillandsia ehlersiana Rauh & Exotic & Herb & Epithyte & Not listed \\
\hline Bromeliaceae & $\begin{array}{l}\text { Tillandsia filifolia Schltdl. } \\
\text { and Cham }\end{array}$ & Exotic & Herb & Epithyte & Not listed \\
\hline Bromeliaceae & Tillandsia funckiana Baker & Exotic & Herb & Epithyte & Not listed \\
\hline Bromeliaceae & Tillandsia ionantha Planch. & $\begin{array}{l}\text { Native not } \\
\text { endemic }\end{array}$ & Herb & Epithyte & $\begin{array}{l}\text { Least Concern } \\
\text { (IUCN) }\end{array}$ \\
\hline Bromeliaceae & Tillandsia jonesii T. Strehl & Native endemic & Herb & Lithophyte & $\begin{array}{l}\text { Critically } \\
\text { endangered } \\
\text { (Martinelli and } \\
\text { Moraes, 2013) }\end{array}$ \\
\hline Bromeliaceae & $\begin{array}{l}\text { Tillandsia juncea (Ruiz and } \\
\text { Pav.) Poir. }\end{array}$ & Exotic & Herb & Epithyte & Not listed \\
\hline Bromeliaceae & Tillandsia nidus Rauh and Lehmann & Exotic & Herb & Epithyte & Not listed \\
\hline Bromeliaceae & Tillandsia schiedeana Steud. & Exotic & Herb & Epithyte & Not listed \\
\hline Bromeliaceae & Tillandsia seleriana $\mathrm{Mez}$ & Exotic & Herb & Epithyte & Not listed \\
\hline Bromeliaceae & $\begin{array}{l}\text { Tillandsia streptophylla Scheidw. } \\
\text { ex C. Morren }\end{array}$ & Exotic & Herb & Epithyte & Not listed \\
\hline
\end{tabular}


Bruno R. Silva et al. / OnLine Journal of Biological Sciences 2018, 18 (4): 401.423 DOI: 10.3844/ojbsci.2018.401.423

\begin{tabular}{|c|c|c|c|c|c|}
\hline Bromeliaceae & Tillandsia tricholepis Baker & $\begin{array}{l}\text { Native not } \\
\text { endemic }\end{array}$ & Herb & Epithyte & Not listed \\
\hline Bromeliaceae & Tillandsia xerographica Rohweder & Exotic & Herb & Epithyte & Not listed \\
\hline Bromeliaceae & Vriesea costae B. R. Silva and Leme & Native endemic & Herb & Lithophyte & $\begin{array}{l}\text { Critically endangered } \\
\text { (Martinelli and } \\
\text { Moraes, 2013) }\end{array}$ \\
\hline Bromeliaceae & $\begin{array}{l}\text { Vriesea saundersii (Carrière) } \\
\text { E. Morren ex Mez }\end{array}$ & Native endemic & Herb & Lithophyte & Not listed \\
\hline Bromeliaceae & Vriesea sp. 1 & Native endemic & Herb & Lithophyte & \\
\hline Bromeliaceae & Wittrockia superba Lindm. & Native endemic & Herb & $\begin{array}{l}\text { Epithyte/ } \\
\text { Lithophyte }\end{array}$ & $\begin{array}{l}\text { Endangered } \\
\text { (Martinelli and Moraes, } \\
\text { 2013) CITES }\end{array}$ \\
\hline Cactaceae & Cactacea sp. 1 & & & & Appendix II \\
\hline Cactaceae & Cactacea sp. 2 & & & & CITES Appendix II \\
\hline Cactaceae & Cactacea sp. 3 & & & & CITES Appendix II \\
\hline Cactaceae & Cactacea sp. 4 & & & & CITES Appendix II \\
\hline Cactaceae & $\begin{array}{l}\text { Coleocephalocereus fluminensis } \\
\text { (Miq.) Backeb. }\end{array}$ & Native endemic & Succulent & Lithophyte & $\begin{array}{l}\text { Endangered } \\
\text { (Martinelli and Moraes, } \\
\text { 2013); CITES } \\
\text { Appendix II }\end{array}$ \\
\hline Cactaceae & Consolea macracantha A. Berger & Exotic & Succulent & $\begin{array}{l}\text { Lithophyte/ } \\
\text { Terrestrial }\end{array}$ & $\begin{array}{l}\text { Least Concern (IUCN); } \\
\text { CITES Appendix II }\end{array}$ \\
\hline Cactaceae & $\begin{array}{l}\text { Echinopsis pachanoi (Britton and } \\
\text { Rose) Friedrich and G.D. Rowley }\end{array}$ & Exotic & Succulent & $\begin{array}{l}\text { Lithophyte/ } \\
\text { Terrestrial }\end{array}$ & $\begin{array}{l}\text { Least Concern (IUCN); } \\
\text { CITES Appendix II }\end{array}$ \\
\hline Cactaceae & Hatiora sp. 1 & & Succulent & Epithyte & CITES Appendix II \\
\hline Cactaceae & $\begin{array}{l}\text { Hylocereus polyrhizus (F.A.C. } \\
\text { Weber) Britton and Rose }\end{array}$ & Exotic & Succulent & $\begin{array}{l}\text { Epithyte/ } \\
\text { Lithophyte }\end{array}$ & CITES Appendix II \\
\hline Cactaceae & $\begin{array}{l}\text { Hylocereus undatus (Haw.) } \\
\text { Britton and Rose }\end{array}$ & $\begin{array}{l}\text { Native not } \\
\text { endemic }\end{array}$ & Succulent & $\begin{array}{l}\text { Epithyte/ } \\
\text { Lithophyte }\end{array}$ & CITES Appendix II \\
\hline Cactaceae & Lepismium cruciform (Vell.) Miq. & $\begin{array}{l}\text { Native not } \\
\text { endemic }\end{array}$ & Succulent & Epithyte & $\begin{array}{l}\text { Least Concern (IUCN); } \\
\text { CITES Appendix II }\end{array}$ \\
\hline Cactaceae & Mammillaria elongata DC. & Exotic & Succulent & Lithophyte & $\begin{array}{l}\text { Least Concern (IUCN); } \\
\text { CITES Appendix II }\end{array}$ \\
\hline Cactaceae & Opuntia ficus-indica (L.) Mill. & $\begin{array}{l}\text { Native not } \\
\text { endemic }\end{array}$ & Succulent & $\begin{array}{l}\text { Lithophyte/ } \\
\text { Terrestrial }\end{array}$ & $\begin{array}{l}\text { Data Deficient (IUCN); } \\
\text { CITES Appendix II }\end{array}$ \\
\hline Cactaceae & Pereskia aculeata Mill. & $\begin{array}{l}\text { Native not } \\
\text { endemic }\end{array}$ & Succulent & $\begin{array}{l}\text { Lithophyte/ } \\
\text { Terrestrial }\end{array}$ & $\begin{array}{l}\text { Least Concern(IUCN); } \\
\text { CITES Appendix II }\end{array}$ \\
\hline Cactaceae & Pereskia grandifolia Haw. & Native endemic & Succulent & $\begin{array}{l}\text { Lithophyte/ } \\
\text { Terrestrial }\end{array}$ & $\begin{array}{l}\text { Least Concern(IUCN); } \\
\text { CITES Appendix II }\end{array}$ \\
\hline Cactaceae & Pilosocereus pachycladus F. Ritter & Native endemic & Succulent & $\begin{array}{l}\text { Lithophyte/ } \\
\text { Terrestrial }\end{array}$ & $\begin{array}{l}\text { Least Concern(IUCN); } \\
\text { CITES Appendix II }\end{array}$ \\
\hline Cactaceae & $\begin{array}{l}\text { Pilosocereus ulei (K. Schum.) } \\
\text { Byles and G.D. Rowley }\end{array}$ & Native endemic & Succulent & Lithophyte & $\begin{array}{l}\text { Endangered Blab(iii) } \\
\text { (IUCN); CITES } \\
\text { Appendix II }\end{array}$ \\
\hline Cactaceae & Rhipsalis baccifera (Sol.) Stearn & $\begin{array}{l}\text { Native not } \\
\text { endemic }\end{array}$ & Succulent & Epithyte & $\begin{array}{l}\text { Least Concern(IUCN); } \\
\text { CITES Appendix II }\end{array}$ \\
\hline Cactaceae & $\begin{array}{l}\text { Rhipsalis cereoides (Backeb. } \\
\text { and Voll) Backeb. }\end{array}$ & Native endemic & Succulent & Lithophyte & $\begin{array}{l}\text { Near Threatened } \\
\text { (IUCN); Critically } \\
\text { endangered (Martinelli } \\
\text { and Moraes, 2013); } \\
\text { CITES Appendix II }\end{array}$ \\
\hline Cactaceae & Rhipsalis clavata F.A.C.Weber & Native endemic & Succulent & Epithyte & $\begin{array}{l}\text { Near threatened } \\
\text { (IUCN); CITES } \\
\text { Appendix II }\end{array}$ \\
\hline Cactaceae & $\begin{array}{l}\text { Rhipsalis elliptica } \text { G. Lindb. Ex } \\
\text { K. Schum. }\end{array}$ & Native endemic & Succulent & Epithyte & $\begin{array}{l}\text { Least Concern } \\
\text { (IUCN); CITES } \\
\text { Appendix II }\end{array}$ \\
\hline Cactaceae & $\begin{array}{l}\text { Rhipsalis ewaldiana Barthlott } \\
\text { and N.P.Taylor }\end{array}$ & Native endemic & Succulent & Epithyte & $\begin{array}{l}\text { Data Deficient } \\
\text { (IUCN); CITES } \\
\text { Appendix II }\end{array}$ \\
\hline Cactaceae & $\begin{array}{l}\text { Rhipsalis flagelliformis N.P. } \\
\text { Taylor and Zappi }\end{array}$ & Native endemic & Succulent & Epithyte & CITES Appendix II \\
\hline Cactaceae & Rhipsalis grandiflora Haw. & Native endemic & Succulent & Epithyte & $\begin{array}{l}\text { Least Concern } \\
\text { (IUCN); CITES } \\
\text { Appendix II }\end{array}$ \\
\hline
\end{tabular}


Bruno R. Silva et al. / OnLine Journal of Biological Sciences 2018, 18 (4): 401.423 DOI: 10.3844/ojbsci.2018.401.423

\begin{tabular}{|c|c|c|c|c|c|}
\hline Cactaceae & Rhipsalis oblonga Loefgr. & Native endemic & Succulent & Epithyte & $\begin{array}{l}\text { Vulnerable B2ab } \\
\text { (ii, iii, iv, v) (IUCN); } \\
\text { CITES Appendix II }\end{array}$ \\
\hline Cactaceae & $\begin{array}{l}\text { Rhipsalis paradoxa (Salm-Dyck } \\
\text { ex Pfeiff.) Salm-Dyck }\end{array}$ & Native endemic & Succulent & $\begin{array}{l}\text { Epithyte/ } \\
\text { Lithophyte }\end{array}$ & $\begin{array}{l}\text { Endangered (Martinelli } \\
\text { and Moraes, 2013); } \\
\text { Least Concern (IUCN); } \\
\text { CITES Appendix II }\end{array}$ \\
\hline Cactaceae & Rhipsalis pentaptera A.Dietr. & Native endemic & Succulent & Epithyte & $\begin{array}{l}\text { Critically Endangered } \\
\text { (IUCN); CITES } \\
\text { Appendix II }\end{array}$ \\
\hline Cactaceae & Rhipsalis sp. 1 & Native endemic & Succulent & Epithyte & CITES Appendix II \\
\hline Cactaceae & Rhipsalis sp. 2 & Native endemic & Succulent & Epithyte & CITES Appendix II \\
\hline Cactaceae & Rhipsalis sp. 3 & Native endemic & Succulent & Epithyte & CITES Appendix II \\
\hline Cactaceae & Rhipsalis sp.4 & Native endemic & Succulent & Epithyte & CITES Appendix II \\
\hline Cactaceae & Rhipsalis sp.5 & Native endemic & Succulent & Epithyte & CITES Appendix II \\
\hline Cactaceae & Rhipsalis sp.6 & Native endemic & Succulent & Epithyte & CITES Appendix II \\
\hline Cactaceae & Rhipsalis sulcata F.A.C.Weber & Native endemic & Succulent & Epithyte & $\begin{array}{l}\text { Data Deficient (IUCN); } \\
\text { CITES Appendix II }\end{array}$ \\
\hline Cactaceae & Rhipsalis teres (Vell.) Steud. & Native endemic & Succulent & Epithyte & $\begin{array}{l}\text { Least Concern(IUCN); } \\
\text { CITES Appendix II }\end{array}$ \\
\hline Cactaceae & Rhipsalis triangularis Werderm. & Native endemic & Succulent & Lithophyte & $\begin{array}{l}\text { Critically Endangered } \\
\text { (IUCN); CITES } \\
\text { Appendix II }\end{array}$ \\
\hline Cactaceae & $\begin{array}{l}\text { Schlumbergera truncata (Haw.) } \\
\text { Moran }\end{array}$ & Native endemic & Succulent & $\begin{array}{l}\text { Epithyte/ } \\
\text { Lithophyte }\end{array}$ & $\begin{array}{l}\text { Vulnerable (IUCN); } \\
\text { CITES Appendix II }\end{array}$ \\
\hline Cactaceae & $\begin{array}{l}\text { Selenicereus anthonyanus } \\
\text { (Alexander) D.R. Hunt }\end{array}$ & Exotic & Succulent & Epithyte & $\begin{array}{l}\text { Least concern (IUCN); } \\
\text { CITES Appendix II }\end{array}$ \\
\hline Cactaceae & $\begin{array}{l}\text { Selenicereus grandiflorus (L.) } \\
\text { Britton and Rose }\end{array}$ & Exotic & Succulent & $\begin{array}{l}\text { Epithyte/ } \\
\text { Lithophyte }\end{array}$ & $\begin{array}{l}\text { Least concern (IUCN); } \\
\text { CITES Appendix II }\end{array}$ \\
\hline Cactaceae & $\begin{array}{l}\text { Selenicereus megalanthus (K. } \\
\text { Schum. ex Vaupel) Moran }\end{array}$ & Exotic & Succulent & $\begin{array}{l}\text { Epithyte/ } \\
\text { Lithophyte }\end{array}$ & CITES Appendix II \\
\hline Cactaceae & Selenicereus sp. 1 & & Succulent & Epithyte & CITES Appendix II \\
\hline Cactaceae & $\begin{array}{l}\text { Weberocereus bradei (Britton and } \\
\text { Rose) G.D. Rowley }\end{array}$ & Exotic & Succulent & Epithyte & $\begin{array}{l}\text { Vulnerable (IUCN); } \\
\text { CITES Appendix II }\end{array}$ \\
\hline Cactaceae & $\begin{array}{l}\text { Winterocereus aureispinus (F. } \\
\text { Ritter) Backeb. }\end{array}$ & Exotic & Succulent & Lithophyte & $\begin{array}{l}\text { Endangered (IUCN); } \\
\text { CITES Appendix II }\end{array}$ \\
\hline Cactaceae & $\begin{array}{l}\text { Winterocereus colademononis (Diers } \\
\text { and Krahn) Metzing and R. Kiesling }\end{array}$ & Exotic & Succulent & $\begin{array}{l}\text { Epithyte/ } \\
\text { Lithophyte }\end{array}$ & CITES Appendix II \\
\hline Cactaceae & Winterocereus sp. & & Succulent & $\begin{array}{l}\text { Epithyte/ } \\
\text { Lithophyte }\end{array}$ & CITES Appendix II \\
\hline Clusiaceae & Clusia fluminensis (landscape clone) & Native endemic & Tree - small & & Not listed \\
\hline Clusiaceae & $\begin{array}{l}\text { Clusia fluminensis Planch. and } \\
\text { Triana }\end{array}$ & Native endemic & Tree - small & Lithophyte & Not listed \\
\hline Commelinaceae & Callisia fragrans (Lindl.) Woodson & Exotic & Succulent & $\begin{array}{l}\text { Lithophyte/ } \\
\text { Terrestrial }\end{array}$ & Not listed \\
\hline Commelinaceae & Callisia repens (Jacq.) L. & Exotic & Herb & $\begin{array}{l}\text { Lithophyte/ } \\
\text { Terrestrial }\end{array}$ & Not listed \\
\hline Commelinaceae & $\begin{array}{l}\text { Callisia warszewicziana } \\
\text { (Kunth and Bouché) D. R. Hunt }\end{array}$ & Exotic & Herb & $\begin{array}{l}\text { Lithophyte/ } \\
\text { Terrestrial }\end{array}$ & Not listed \\
\hline Commelinaceae & $\begin{array}{l}\text { Tradescantia pallida var. purpurea } \\
\text { Rose) D.R. Hunt }\end{array}$ & Exotic & Herb & $\begin{array}{l}\text { Lithophyte/ } \\
\text { Terrestrial }\end{array}$ & Not listed \\
\hline Commelinaceae & Tradescantia zebrina Heynh. & Exotic & Herb & $\begin{array}{l}\text { Lithophyte/ } \\
\text { Terrestrial }\end{array}$ & Not listed \\
\hline Convolvulaceae & Ipomoea pes-caprae (L.) R. Br. & $\begin{array}{l}\text { Native not } \\
\text { endemic }\end{array}$ & Liana & Psammophilous & Not listed \\
\hline Crassulaceae & $\begin{array}{l}\text { Bryophyllum beauverdii (Raym. } \\
\text {-Hamet) A. Berger }\end{array}$ & Exotic & Liana & $\begin{array}{l}\text { Epithyte/ } \\
\text { Lithophyte }\end{array}$ & Not listed \\
\hline Crassulaceae & $\begin{array}{l}\text { Bryophyllum daigremontianum(Raym. } \\
\text {-Hamet and H. Perrier) A. Berger }\end{array}$ & Exotic & Succulent & $\begin{array}{l}\text { Lithophyte/ } \\
\text { Terrestrial }\end{array}$ & Not listed \\
\hline Crassulaceae & Crassula obliqua Aiton & Exotic & Arbusto suculento & $\begin{array}{l}\text { Lithophyte/ } \\
\text { Terrestrial }\end{array}$ & Not listed \\
\hline Crassulaceae & $\begin{array}{l}\text { Graptopetalum paraguayense } \\
\text { (N.E. Br.) E. Walther }\end{array}$ & Exotic & Succulent & $\begin{array}{l}\text { Lithophyte/ } \\
\text { Terrestrial }\end{array}$ & Not listed \\
\hline Crassulaceae & $\begin{array}{l}\text { Kalanchoe fedtschenkoi } \\
\text { Hamet and H. Perrier }\end{array}$ & Exotic & Succulent & $\begin{array}{l}\text { Lithophyte/ } \\
\text { Terrestrial }\end{array}$ & Not listed \\
\hline
\end{tabular}


Bruno R. Silva et al. / OnLine Journal of Biological Sciences 2018, 18 (4): 401.423 DOI: 10.3844/ojbsci.2018.401.423

\begin{tabular}{|c|c|c|c|c|c|}
\hline Crassulaceae & kalanchoe orgyalis Baker & Exotic & Succulent & $\begin{array}{l}\text { Lithophyte/ } \\
\text { Terrestrial }\end{array}$ & Not listed \\
\hline Crassulaceae & Kalanchoe tubiflora Raym.-Hamet & Exotic & Succulent & $\begin{array}{l}\text { Lithophyte/ } \\
\text { Terrestrial }\end{array}$ & Not listed \\
\hline Didiereaceae & Alluaudia procera (Drake) Drake & Exotic & Árvore succulent & $\begin{array}{l}\text { Lithophyte/ } \\
\text { Terrestrial }\end{array}$ & $\begin{array}{l}\text { Lower Risk/near } \\
\text { threatened (IUCN); } \\
\text { CITES Appendix II }\end{array}$ \\
\hline Doryanthaceae & $\begin{array}{l}\text { Doryanthes palmeri W. Hill } \\
\text { ex Benth. }\end{array}$ & Exotic & Succulent & $\begin{array}{l}\text { Lithophyte/ } \\
\text { Terrestrial }\end{array}$ & $\begin{array}{l}\text { Vulnerable under the } \\
\text { New South Wales } \\
\text { Threatened Species } \\
\text { Act (1995) }\end{array}$ \\
\hline Euphorbiaceae & Euphorbia enterophora Drake & Exotic & Arbusto suculento & $\begin{array}{l}\text { Lithophyte/ } \\
\text { Terrestrial }\end{array}$ & $\begin{array}{l}\text { Least concern (IUCN); } \\
\text { CITES Appendix II }\end{array}$ \\
\hline Euphorbiaceae & Euphorbia sp.2 & & Arbusto suculento & $\begin{array}{l}\text { Lithophyte/ } \\
\text { Terrestrial }\end{array}$ & CITES Appendix II \\
\hline Euphorbiaceae & Euphorbia sp.3 & & Arbusto suculento & $\begin{array}{l}\text { Lithophyte/ } \\
\text { Terrestrial }\end{array}$ & CITES Appendix II \\
\hline Euphorbiaceae & Ricinus communis L. & Exotic & Tree - small & Terrestrial & Not listed \\
\hline Iridaceae & $\begin{array}{l}\text { Neomarica caerulea (Ker } \\
\text { Gawl.) Sprague }\end{array}$ & Native endemic & Herb & $\begin{array}{l}\text { Lithophyte/ } \\
\text { Terrestrial }\end{array}$ & Not listed \\
\hline Lamiaceae & Rosmarinus officinalis L. & Exotic & Shrub - large & $\begin{array}{l}\text { Lithophyte/ } \\
\text { Terrestrial }\end{array}$ & Not listed \\
\hline Melastomataceae & $\begin{array}{l}\text { Heterocentron elegans } \\
\text { (Schltdl.) Kuntze }\end{array}$ & Exotic & Liana & $\begin{array}{l}\text { Lithophyte/ } \\
\text { Terrestrial }\end{array}$ & Not listed \\
\hline Melastomataceae & $\begin{array}{l}\text { Tibouchina heteromalla } \\
\text { (D.Don) Cogn. }\end{array}$ & Native endemic & Shrub - large & $\begin{array}{l}\text { Lithophyte/ } \\
\text { Terrestrial }\end{array}$ & Not listed \\
\hline Orchidaceae & Aganisia cyanea (Schltr.) Rchb.f. & $\begin{array}{l}\text { Native not } \\
\text { endemic }\end{array}$ & Herb & Epithyte & CITES Appendix II \\
\hline Orchidaceae & Arundina bambusifolia Lindl. & Exotic & Herb & Terrestrial & CITES Appendix II \\
\hline Orchidaceae & Brassavola tuberculata Hook. & Native endemic & Herb & $\begin{array}{l}\text { Epithyte/ } \\
\text { Lithophyte }\end{array}$ & CITES Appendix II \\
\hline Orchidaceae & Cattleya intermedia Grah. & Native endemic & Herb & $\begin{array}{l}\text { Epithyte/ } \\
\text { Lithophyte }\end{array}$ & $\begin{array}{l}\text { Vulnerable (Martinelli } \\
\text { and Moraes, 2013); } \\
\text { CITES Appendix II }\end{array}$ \\
\hline Orchidaceae & Cattleya schilleriana Rchb. f. & Native endemic & Herb & Epithyte & $\begin{array}{l}\text { Endangered (Martinelli } \\
\text { and Moraes, 2013); } \\
\text { CITES Appendix II }\end{array}$ \\
\hline Orchidaceae & $\begin{array}{l}\text { Coilostylis parkinsoniana (Hook.) } \\
\text { Withner and P.A.Harding }\end{array}$ & Exotic & Herb & Epithyte & CITES Appendix II \\
\hline Orchidaceae & Cyrtopodium glutiniferum Raddi & Native endemic & Herb & Lithophyte & CITES Appendix II \\
\hline Orchidaceae & Dendrobium anceps Sw. & Exotic & Herb & Epithyte & CITES Appendix II \\
\hline Orchidaceae & Epidendrum ibaguense Kunth & $\begin{array}{l}\text { Native not } \\
\text { endemic }\end{array}$ & Herb & $\begin{array}{l}\text { Lithophyte/ } \\
\text { Terrestrial }\end{array}$ & CITES Appendix II \\
\hline Orchidaceae & Epidendrum secundum Jacq. & Native not enden & Herb & Epithyte & $\begin{array}{l}\text { Least concern: Red list } \\
\text { CNCFLORA; CITES } \\
\text { Appendix II }\end{array}$ \\
\hline Orchidaceae & Epidendrum sp.1 & Native endemic & Herb & Lithophyte & CITES Appendix II \\
\hline Orchidaceae & Epidendrum vesicatum Lindl. & Native endemic & Herb & Epithyte & $\begin{array}{l}\text { Least concern: Red list } \\
\text { CNCFLORA; CITES } \\
\text { Appendix II }\end{array}$ \\
\hline Orchidaceae & $\begin{array}{l}\text { Myrmecophila tibicinis } \\
\text { (Bateman) Rolfe }\end{array}$ & Exotic & Herb & Epithyte & CITES Appendix II \\
\hline Orchidaceae & Vanilla chamissonis Klotzsch & $\begin{array}{l}\text { Native not } \\
\text { endemic }\end{array}$ & Liana & $\begin{array}{l}\text { Epithyte/ } \\
\text { Lithophyte }\end{array}$ & CITES Appendix II \\
\hline Pandanaceae & Pandanus baptistii Misonne & Exotic & Herb & $\begin{array}{l}\text { Lithophyte/ } \\
\text { Terrestrial }\end{array}$ & Not listed \\
\hline Pandanaceae & Pandanus utilis Bory & Exotic & Tree - small & Terrestrial & Not listed \\
\hline Piperaceae & Peperomia serpens (Sw.) Loudon & Native not & Liana & $\begin{array}{l}\text { Epithyte } \\
\text { endemic }\end{array}$ & $\begin{array}{l}\text { Least concern: Red list } \\
\text { CNCFLORA }\end{array}$ \\
\hline Polypodiaceae & $\begin{array}{l}\text { Phlebodium decumanum } \\
\text { (Willd.) J. Sm. }\end{array}$ & $\begin{array}{l}\text { Native not } \\
\text { endemic }\end{array}$ & Herb & Epithyte & Not listed \\
\hline Polypodiaceae & $\begin{array}{l}\text { Platycerium bifurcatum (Cav.) } \\
\text { C. Chr. }\end{array}$ & Exotic & Herb & Epithyte & Not listed \\
\hline Xanthorrhoeaceae & Aloe sp. & Exotic & & & \\
\hline Xanthorrhoeaceae & Aloe aculeata Pole-Evans & Exotic & Succulent & Lithophyte & CITES Appendix II \\
\hline
\end{tabular}


Bruno R. Silva et al. / OnLine Journal of Biological Sciences 2018, 18 (4): 401.423 DOI: 10.3844/ojbsci.2018.401.423

\begin{tabular}{|c|c|c|c|c|c|}
\hline Xanthorrhoeaceae & Aloe arborescens Mill. & Exotic & Succulent & $\begin{array}{l}\text { Lithophyte/ } \\
\text { Terrestrial }\end{array}$ & CITES Appendix II \\
\hline Xanthorrhoeaceae & Aloe aristata Haw. & Exotic & Succulent & $\begin{array}{l}\text { Lithophyte/ } \\
\text { Terrestrial }\end{array}$ & CITES Appendix II \\
\hline Xanthorrhoeaceae & Aloe dawei A. Berger & Exotic & Succulent & $\begin{array}{l}\text { Lithophyte/ } \\
\text { Terrestrial }\end{array}$ & CITES Appendix II \\
\hline Xanthorrhoeaceae & Aloe petrophila Pillans & Exotic & Succulent & $\begin{array}{l}\text { Lithophyte/ } \\
\text { Terrestrial }\end{array}$ & CITES Appendix II \\
\hline Xanthorrhoeaceae & Aloe vera (L.) Burm. f. & Exotic & $\begin{array}{l}\text { Succulent } \\
\text { Terrestrial }\end{array}$ & Lithophyte/ & Not listed \\
\hline
\end{tabular}

